\title{
Comprehensive insight into triclosan-from widespread occurrence to health outcomes
}

\author{
Maja Milanović ${ }^{1}\left[\right.$ ] Larisa Đurić ${ }^{1} \cdot$ Nataša Milošević ${ }^{1} \cdot$ Nataša Milić $^{1}$
}

Received: 17 May 2021 / Accepted: 25 October 2021 / Published online: 6 November 2021

(c) The Author(s), under exclusive licence to Springer-Verlag GmbH Germany, part of Springer Nature 2021

\begin{abstract}
Humans are exposed to the variety of emerging environmental pollutant in everyday life. The special concern is paid to endocrine disrupting chemicals especially to triclosan which could interfere with normal hormonal functions. Triclosan could be found in numerous commercial products such as mouthwashes, toothpastes and disinfectants due to its antibacterial and antifungal effects. Considering the excessive use and disposal, wastewaters are recognized as the main source of triclosan in the aquatic environment. As a result of the incomplete removal, triclosan residues reach surface water and even groundwater. Triclosan has potential to accumulate in sediment and aquatic organisms. Therefore, the detectable concentrations of triclosan in various environmental and biological matrices emerged concerns about the potential toxicity. Triclosan impairs thyroid homeostasis and could be associated with neurodevelopment impairment, metabolic disorders, cardiotoxicity and the increased cancer risk. The growing resistance of the vast groups of bacteria, the evidenced toxicity on different aquatic organisms, its adverse health effects observed in vitro, in vivo as well as the available epidemiological studies suggest that further efforts to monitor triclosan toxicity at environmental levels are necessary. The safety precaution measures and full commitment to proper legislation in compliance with the environmental protection are needed in order to obtain triclosan good ecological status. This paper is an overview of the possible negative triclosan effects on human health. Sources of exposure to triclosan, methods and levels of detection in aquatic environment are also discussed.
\end{abstract}

Keywords Triclosan $\cdot$ Antimicrobial agent $\cdot$ Personal care product $\cdot$ Endocrine disrupting chemical $\cdot$ Emerging environmental pollutant $\cdot$ Environmental pollution $\cdot$ Adverse health effects

\section{Introduction}

Humans are exposed to the vast range of chemicals in everyday life, and the major issue nowadays presents substances that could interfere with endocrine system through alteration of receptor expression and/or hormone synthesis, metabolism, transport, distribution and clearance (Milanović et al. 2016; Gao et al. 2021; La Merrill et al. 2020). Endocrine disrupting chemicals (EDCs) are defined as 'an exogenous substance or mixture that alters function(s) of the endocrine system and consequently causes adverse health effects in an

Communicated by Hongwen Sun

Maja Milanović

maja.milanovic@mf.uns.ac.rs

1 University of Novi Sad, Faculty of Medicine, Department of Pharmacy, Novi Sad, Serbia intact organism, or its progeny, or (sub)populations' (European Commission 2020).

EDCs are all around us, in food, food contact materials, textile, electronics, plastic, medical devices, cosmetics, personal care products, etc. Although the impact of chronic EDC exposure on human health represents relatively new toxicological and eco-toxicological issue, the concerns of the various scientific institutions and regulatory bodies worldwide are rapidly growing. The reasons are reflected in the increased trends of endocrine-related diseases and their evidence-based association with EDCs (Milić et al. 2015; Milošević et al. 2017, 2018, 2020; Milanović et al. 2020). However, EDCs are a heterogeneous set of chemical compounds, and the information about the relationship between exposure to an EDC and a certain disorder are mostly incomplete. Consequently, there are still inconsistencies in the regulation of EDCs. 
Fig. 1 Sources and pathways of human exposure to triclosan

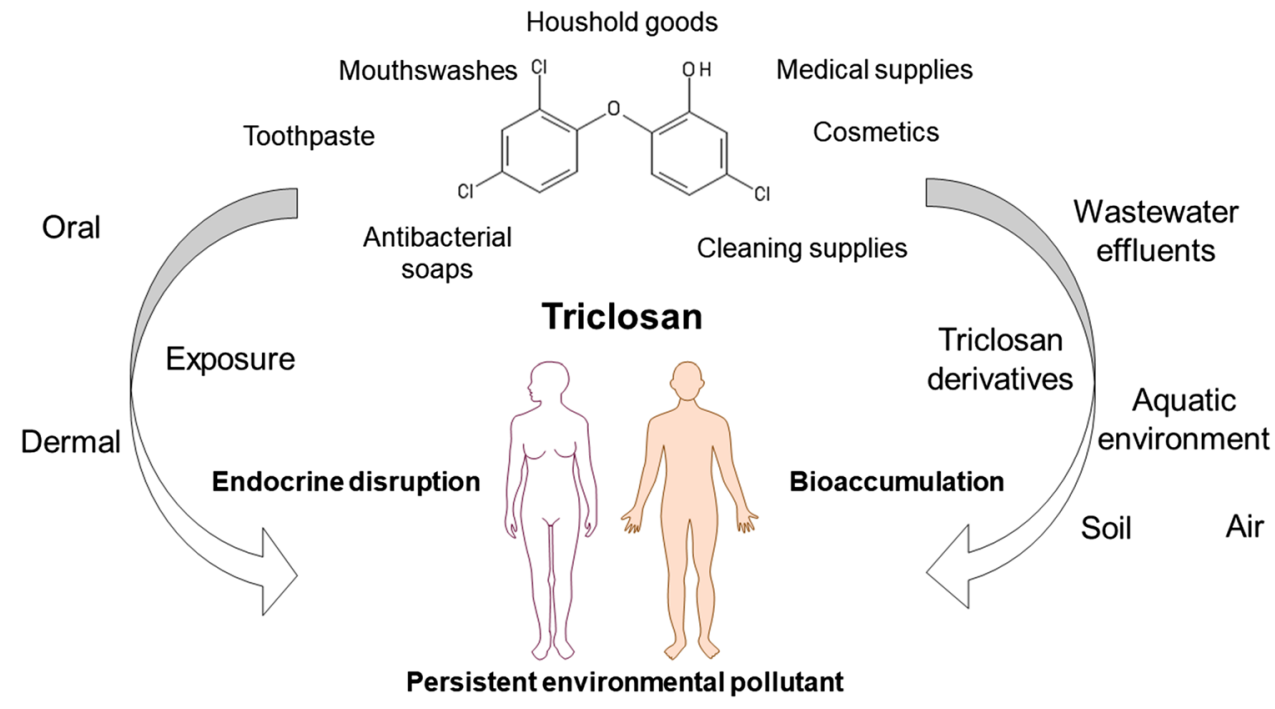

Triclosan (TCS, 5-chloro-2-(2,4-dichlorophenoxy) phenol) is a synthetic, multi-purpose antimicrobial agent which could be found as an ingredient in mouthwashes, toothpastes, soaps, disinfectants, deodorants, clothing textiles, furniture and other materials (Dhillon et al. 2015). TCS in commercial products could also be named Irgasan (Lee et al. 2019). It has been estimated that 1500 tons of TCS is globally produced per year, and 132 million liters of TCS-containing products are used annually only in the USA (Alfhili and Lee 2019). Probably, the production rates have changed since the outbreak of coronavirus disease 2019 (COVID-19) due to the high demand for disinfection (Chu et al. 2020; Ejtahed et al. 2020; Usman et al. 2020).

Halogenated biphenyl ether structure of TCS is stable to hydrolysis (in the $\mathrm{pH}$ range 4-9) and is related to other EDCs such as bisphenol A (BPA) and dioxins (Montaseri and Forbes 2016). The US National Institute of Environmental Health Sciences (NIEHS) and Environmental Protection Agency (EPA) declare TCS as an EDC (NIEHS 2020), while according to the European Food Safety Authority (EFSA) and European Chemical Agency (ECHA), it is still under assessment as EDCs (ECHA 2020). The environmental and human toxicology data about TCS suggest the acute toxicity to aquatic organisms and potential human carcinogenicity, mild genotoxicity, endocrine disruption and induction of antimicrobial resistance (Huang et al. 2014a; Li 2021). However, the adequate regulatory evaluation of TCS usage and exposure limits are still incomplete.

The TCS use in the over-the-counter antiseptic wash products (liquid, foam, soaps and body washes) has been banned by the United States Food and Drug Administration (FDA) since 2016. However, the hand sanitizers, wipes and other TCS-containing products are not yet regulated by FDA (FDA 2016). On the contrary, the use of TCS as biocide as well as in food contact materials has been banned in the European Union, while its application in personal care products is still allowed (European Commission 2020). According to the European Commission as well as the national standards set by Canada, the USA and China, the maximum allowed TCS concentration in soaps, deodorants and mouth products should not exceed $0.3 \%(\mathrm{w} / \mathrm{w})$ (Wang and Liang 2021). Japan decided to decrease the allowable TCS limits in cosmetic products $(0.1 \%)$, while there is still no rule in Norway regarding TCS maximum allowable concentration (Cosmetic Ingredient Review (CIR) 2010). Besides the differences in regulations of some cases, it presents a real challenge to ensure compliance and additional efforts that could be required. Today, disinfectants and antiseptic wash products are essential in the control and prevention of devastating spread of SARS-CoV-2 virus (Dhama et al. 2021). However, the excessive use and disposal of TCS containing disinfectants and antiseptics raise concerns to the negative effects on the human health and the environment (Mukherjee et al. 2021). Therefore, further efforts regarding the monitoring of possible related TCS health effects and safety precaution measures are necessary in order to achieve not only the harmonization of the global legislation regarding TCS but also the long-term health and environmental benefits.

This paper aims to provide an overview of the potential sources of TCS exposure with the detected concentrations in the environment and biological matrices, methods of analyses and its removal. The special attention is paid to the TCSassociated risk to human health.

\section{Sources of TCS exposure}

Possible sources of human exposure to triclosan are presented in Fig. 1. Over $80 \%$ of TCS usage is contributed to cosmetics, various personal care products and household cleaning products which contain mostly between 0.1 and $0.3 \%$ of TCS (Gao et al. 2018). However, TCS-containing personal care products 
are recognized as the primary source of TCS, although the maximum allowed concentration of TCS in different products varies worldwide. Besides toothpastes, antibacterial and deodorant soaps, dishwashing liquids and antiperspirants/deodorants, TCS is found in a wide range of consumer products as a material preservative (kitchen utensils, toys, clothes, fabrics, etc.) (Dhillon et al. 2015; Zhu et al. 2020).

Based on the TCS exposure study conducted in Korea, the systemic exposure dosage (SED) was $0.4952 \mu \mathrm{mol} / \mathrm{kg}$ of body weight per day depending on the sum of representative cosmetic and oral care products. If only the rinse-off cosmetics, deodorants, color cosmetics as well as oral care products were considered, SED would be $0.1635 \mu \mathrm{mol} / \mathrm{kg}$ of body weight per day (Lee et al. 2019; Park et al. 2019). According to the Scientific Committee on Consumer Safety (SCCS) noobserved-adverse-effect level (NOAEL) of TCS is $41.44 \mu \mathrm{mol} /$ $\mathrm{kg}$ of body weight per day based on the established chronic hematoxicity and the decreased spleen mass in rats, whereas exposure to TCS through inhalation was not considered. However, EPA calculated NOAEL remained almost three times higher, $103.61 \mu \mathrm{mol} / \mathrm{kg}$ of body weight (Scientific Committee on Consumer Safety (SCCS) 2011).

Besides the direct use of TCS products, the exposure to TCS via air, surface water, drinking water and soil is also possible and could lead to the long-term exposure to TCS. It has been estimated that more than a half of the amount of the total TCS consumed is directly discharged into the environment (Huang et al. 2014a).

\section{Occurrence of TCS in different environmental matrices}

\section{Air}

Considering the low volatility of TCS, the TCS mass distribution in air is less than $1 \%$, and it is believed that air is the least migration pathway for TCS (Zhang et al. 2021). Therefore, the limited number of studies has been available in the literature up to now. Regarding the frequent usage of TCS as a material preservative, it was detected in $100 \%$ of the indoor dust samples (Zhu et al. 2020). Interestingly, based on the study conducted in France, TCS concentrations varied between the observed locations (house, apartment, day nursery and office), and the office was identified as the most contaminated site $\left(0.794 \mathrm{pmol} / \mathrm{m}^{3}\right)$ (Laborie et al. 2016). The TCS was also measured in $100 \%$ of indoor dust from Beijing at the levels up to $4075.4 \mathrm{nmol} / \mathrm{kg}$ (Wang et al. 2021). However, TCS was found in much lower concentrations (up to $759.8 \mathrm{nmol} / \mathrm{kg}$ ) in indoor dust samples in Belgium (Geens et al. 2009a).

In the recently published study, the positive correlations were found between urinary TCS levels and indoor dust samples (Zhang et al. 2021). Based on the paired human urine and indoor dust samples, the addition of indoor dust ingestion to the total TCS exposure was minor (Zhang et al. 2021; Wang et al. 2021). However, the obtained findings imply that indoor dust is also an important source of human exposure to TCS.

\section{Occurrence and removal of TCS from wastewater}

TCS-containing personal care products are recognized as the primary source of TCS in wastewater. It is supposed that TCS reaches surface water, ground water, soil and ultimately drinking water via municipal and industrial wastewater effluent, due to the incomplete removal and/ or lack of wastewater treatment plants (WWTPs) (Huang et al. 2014a).

Although, the highest TCS concentration was measured in raw wastewater in the USA $(297.7 \mathrm{nM})$, TCS was detected at high level in both raw and treated wastewater in South Africa (60.8 nM versus $44.9 \mathrm{nM}$, Table 1) (Kumar et al. 2010; Lehutso et al. 2017). The available wastewater treatment technologies vary among the countries, and the differences are more pronounced between developing and developed countries. Advanced treatment methods are relatively scarce in the developing world (Wee et al. 2020). Some cities, even in Europe, are still without an urban waste water treatment plant (Milanović et al. 2016).

The increased TCS concentrations in influent were followed with the decreased in effluent in Australia (Ying and Kookana 2007), Thailand (Juksu et al. 2019) and UK (Petrie et al. 2016) (Table 1). The TCS removal from wastewater depends strongly on its physicochemical properties (Lee 2015). The lipophilic character of TCS is related to the high sorption potential. TCS is mostly removed via biodegradation or adsorption, and WWTP removal efficiency could be up to $99 \%$ (Olaniyan et al. 2016). Some of the commonly applied biological treatment methods are activated sludge process, trickling filters, oxidation ditches and rotating biological contactors (Jagini et al. 2019). It was observed that the removal efficiency was more than three times higher during the aerobic conditions compared with anaerobic $(97 \%$ versus 30\%) (Gangadharan et al. 2012). Additionally, the removal efficiency could be affected by temperature, $\mathrm{pH}$ value as well as by the lipid, protein and carbohydrate contents (Winkler et al. 2007).

Activated carbon, carbon nanotubes, zeolite, clay and the adsorption with biochar were also tested for the removal of TCS (Kaur et al. 2018). Additionally, polymeric resins showed high adsorption of TCS (99\%) (Solak et al. 2014), and among different types of membrane technologies, ultrafiltration was observed as the highly efficient method (Sheng et al. 2016). Although the adsorption is efficient ( $80 \%$ ) in TCS removal, the large quantity of the solid residue 


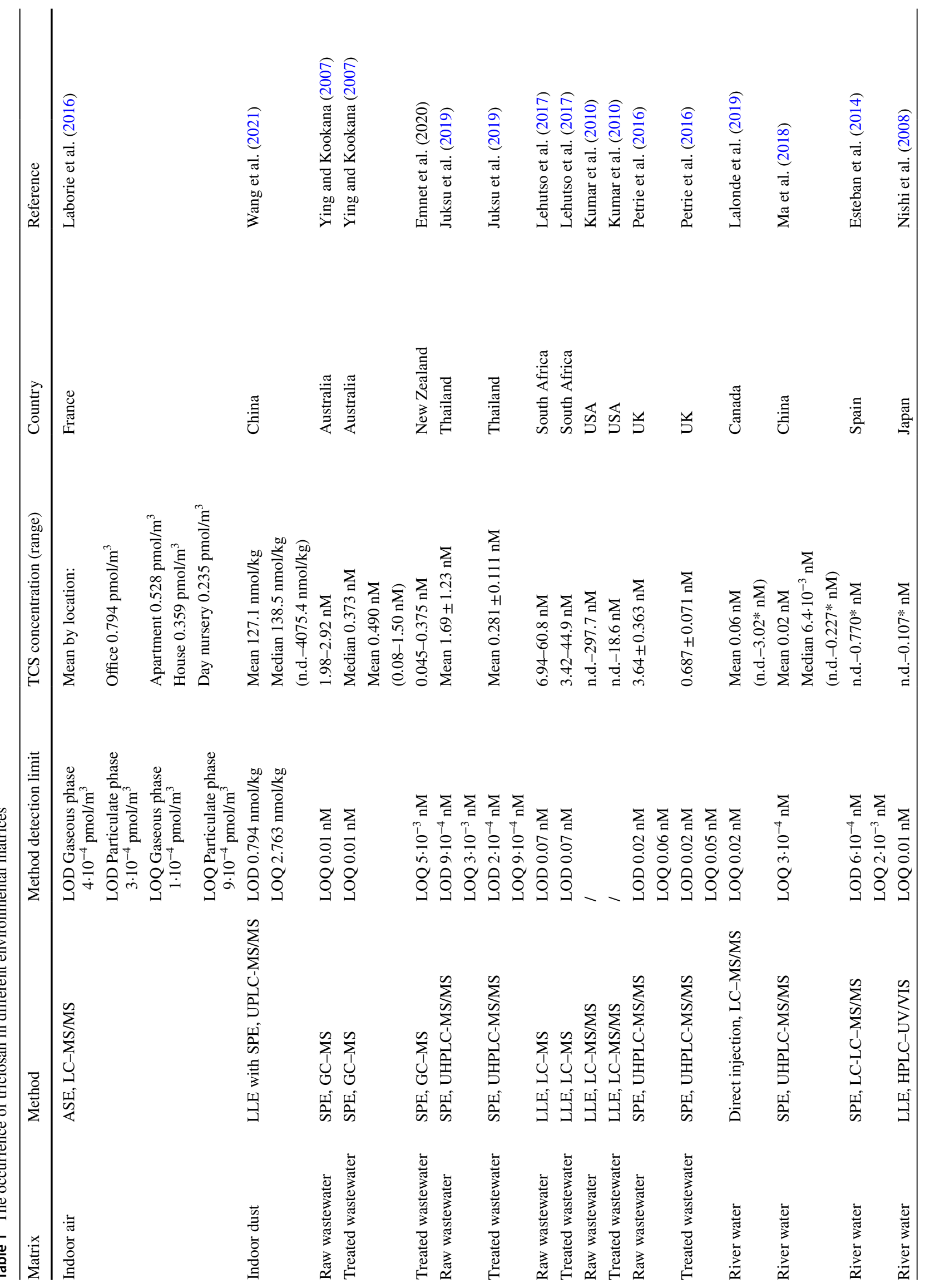




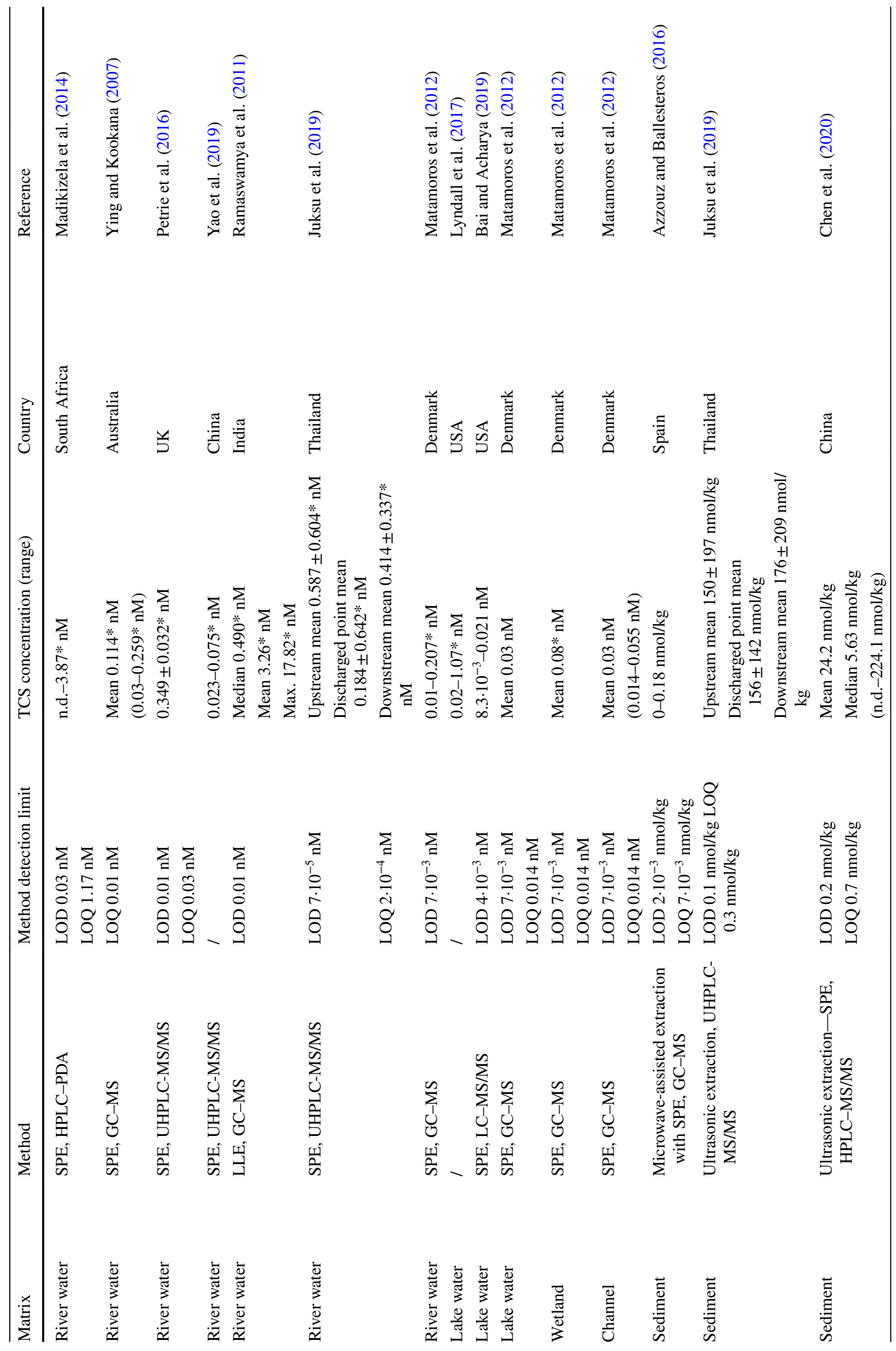




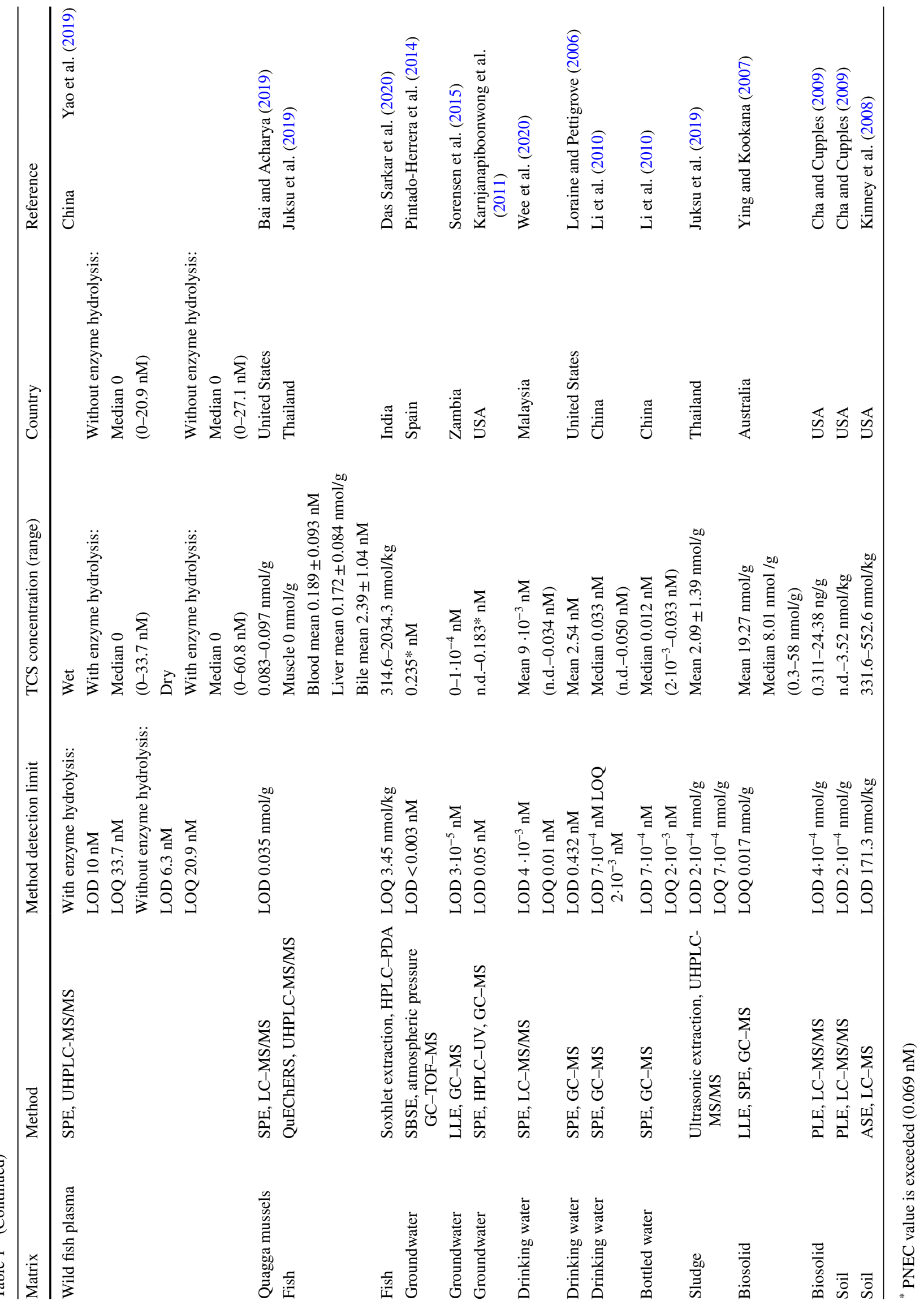


requires the further treatment (Luo et al. 2019). The efficient removal from the sludge could be met by trickling filters ( $>$ 90\%) (Winkler et al. 2007). However, in the sewage sludge, the microbial activity transforms TCS to methyl triclosan (MTCS). After biological treatment, MTCS was detected in wastewater (mean $0.037 \mathrm{nM}$ ), treated sludge (mean $0.446 \mathrm{nmol} / \mathrm{g}$ ) as well as in surface water in the concentrations up to $0.02 \mathrm{nM}$ (Tohidi and Cai 2015; Wang and Kelly 2017).

Nevertheless, the main removal TCS pathway from water sources is still oxidation. Particularly, photocatalysis is more appropriate for TCS removal from wastewater (Hippargi et al. 2021; Kaur et al. 2020). TCS is identified as biodegradable, photo-unstable, and chlorine and ozone readily reactive. Although oxidation techniques (such as chlorination, ozonation, Fenton processes, photolysis/photocatalysis and electrochemical oxidation) demonstrated the high TCS removal efficiency, chlorination and photooxidation can result in the formation of hazardous compounds (Bedoux et al. 2012; Luo et al. 2019). Chlorinated TCS derivatives and dioxins such as 2,8-dichlorodibenzo-P-dioxin (2,8DCDD), 2,4-dichlorophenol and 2,4,6-trichlorophenol are more toxic than the parent TCS (Aranami and Readman 2007; Olaniyan et al. 2016; Reiss et al. 2002). These compounds are associated with serious effects such as genotoxicity, mutagenicity and carcinogenicity (Adithya et al. 2021). It is worth noting that chlorination triggers the endocrine disruption and results in 30-fold higher TCS anti-estrogenic activity (Li 2021). The TCS degradation products seem to be more persistent with higher bioaccumulation potential, due to its increased lipophilicity and volatility (Tohidi and Cai 2015). Considering all the facts mentioned above, the regular monitoring programs and the comprehensive risk assessment of TCS and TCS degradation products in the surface water are needed in order to protect better both environment and health.

\section{Surface water}

Besides the accomplished advances in WWTPs, the complete removal of TCS is still hard to achieve. Therefore, in several studies conducted worldwide, TCS was detected in surface water despite the lipophilic nature and easy absorption into the sediment and sewage sludge (Table 1).

As a part of the priority list review process within the Water Frame Directive, the Joint Research Centre conducted a large survey in 10 countries at 686 sampling sites, and TCS was quantified in more than $40 \%$ inland whole water samples (in total 5430 analyzed samples) with the maximum detected concentration of $96.7 \mathrm{nM}$ (Carvalho et al. 2016). It is worth noting that TCS was prioritized as one of the top ten specific pollutants among 500 pollutants in the Elbe River basin (von der Ohe et al. 2011). In Europe, the detected
TCS concentrations in different river bodies significantly varied from $0.207 \mathrm{nM}$ in Denmark to $0.770 \mathrm{nM}$ in Spain (Esteban et al. 2014; Matamoros et al. 2012). The measured concentrations of TCS were significantly higher in India (up to $17.8 \mathrm{nM}$ ), South Africa (up to $3.1 \mathrm{nM}$ ) and Canada ( $3 \mathrm{nM}$ ) compared to Japan $(0.107 \mathrm{nM})$, China $(0.227 \mathrm{nM})$ and the USA (1.1 nM) (Lalonde et al. 2019; Ma et al. 2018; Madikizela et al. 2014; Nishi et al. 2008; Ramaswamya et al. 2011).

Owing to the bioaccumulation potential (von der Ohe et al. 2012), TCS presence was detected in sediment and aquatic organisms such as wild fish plasma, quagga mussels and fish (Bai and Acharya 2019; Das Sarkar et al. 2020; Juksu et al. 2019; Yao et al. 2019). TCS was even found in the 30-year-old sediment cores (Singer et al. 2002). Hence, TCS is proposed as a contaminant that is mainly associated with the acute and genetic toxicity in the sediment (Chen et al. 2015).

Based on the reported values given in Table 1, TCS concentrations in surface water were several times higher than the predicted no observed effect concentration (PNEC) of TCS set by European Commission (0.069 nM). Hence, the current prioritization methodology of TCS is questionable due to the growing resistance of the vast groups of bacteria and the demonstrated TCS toxicity toward different aquatic organisms at the environmental levels (Khatikarn et al. 2018; Lydon et al. 2018; Westfall et al. 2019).

\section{Groundwater}

Due to the widespread exposure, TCS could be even found in groundwater samples. Despite the limited number of studies, TCS levels in groundwater ranged from $0.0001 \mathrm{nM}$ in Zambia, $0.183 \mathrm{nM}$ in the USA to even $0.235 \mathrm{nM}$ in Spain (Karnjanapiboonwong et al. 2011; Pintado-Herrera et al. 2014; Sorensen et al. 2015).

\section{Drinking water}

Regarding the drinking water samples, TCS was measured in the USA in the extremely high concentrations up to $2.54 \mathrm{nM}$ (Perez et al. 2013). TCS was also detected in drinking water samples in Malaysia (up to $0.034 \mathrm{nM})$, China $(0.05 \mathrm{nM})$ and Taiwan (up to $0.356 \mathrm{nM}$ ) (Yang et al. 2014; Wee et al. 2020). In bottled water, TCS was detected with high frequency (in 18 out of 21 samples in China), but in lower concentration $(0.033 \mathrm{nM}$ in bottled water versus $0.05 \mathrm{nM}$ in tap water) $(\mathrm{Li}$ et al. 2010).

\section{Soil}

Due to the high lipophilicity, TCS is easily adsorbed into sewage sludge and can be found in the biosolids and agricultural soils, presenting a high risk for entering the food chain 
via agricultural products. The application of recycled water for irrigation purposes is also associated with the occurrence of TCS in soils (Mendez et al. 2016). Although about $50 \%$ of biosolids are land applied in the USA, the available data about the TCS concentration in soil are still limited. TCS levels in soil samples, after the application of biosolids, ranged from 0.562 to $3.52 \mathrm{nmol} / \mathrm{kg}$ (Cha and Cupples 2009). In another study, TCS was measured in much higher concentration (331.6-552.6 nmol/kg) after the land application of biosolids (Kinney et al. 2008). In sludge, detected levels of TCS were $3.48 \mathrm{nmol} / \mathrm{g}$ in Thailand, whereas in biosolids $32.05 \mathrm{nmol} / \mathrm{g}$ in the USA and even $57.9 \mathrm{nmol} / \mathrm{g}$ in Australia (Cha and Cupples 2009; Juksu et al. 2019; Ying and Kookana 2007).

The half-life of TCS in aerobic soil was 18 days (Dhillon et al. 2015), and the bioaccumulation potential of triclosan was observed in different fruits, root crops, radish, soybean plants, lettuce and pinto beans (Karnjanapiboonwong.et al. 2011; Calderon-Preciado et al. 2012). TCS was found in edible parts of onions (up to $1.5 \mathrm{nmol} / \mathrm{g}$ ) when the plant was cultivated in irrigated soil with TCS environmental concentrations (0-5 nM) (Mendez et al. 2016). In radish almost the same TCS concentration was obtained as in the cultivated soil (31.8 $\mu \mathrm{mol} / \mathrm{kg}$ versus $34.2 \mu \mathrm{mol} / \mathrm{kg}$ ) (Pannu et al. 2012). Nevertheless, it was found that biosolid amendment of soils resulted in the increased persistence, plant accumulation and overall ecotoxicological risk of TCS (Fu et al. 2016).

\section{TCS pharmacokinetics}

Considering the fact that TCS was measured in various types of environmental compartments, it can be considered as a ubiquitous pollutant. Hence, oral ingestion can be identified as the main source of TCS uptake (Lu et al. 2018). The ingestion of TCS is followed by a rapid gastrointestinal absorption and median urinary excretion of $54 \%$, within 4 days (Sandborgh-Englund et al. 2006). On the contrary, after dermal exposure, which is identified as the second main exposure route, less than $10 \%$ of TCS is absorbed (Queckenberg et al. 2010). Additionally, TCS can be absorbed through the oral mucous membrane (Weatherly and Gosse 2017).

Owing to the lipophilic properties, TCS is mainly distributed in liver and adipose tissue. During the metabolism mostly performed in liver, more polar TCS metabolites are formed (Moss et al. 2000). In an in vitro study, using human and rat liver fractions, it was found that in phase I, glutathione adducts and aromatic hydroxylation products were formed followed by sulphation and glucuronidation in the phase II (Guesmi and Sleno 2020). The cleavage process resulted in the formation of 2,4-dichlorophenol and 4-chlorocatechol that were detected in rat urine and feces (Fang et al. 2010). However, TCS can also be directly conjugated and is mainly excreted in urine as TCS-glucuronide and TCS-sulphate (Sandborgh-Englund et al. 2006).

Regardless the route of exposure, TCS is primary excreted via urine, with the elimination half-life around $11 \mathrm{~h}$ (Queckenberg et al. 2010; Sandborgh-Englund et al. 2006). Therefore, urinary TCS is predominantly used as a biomarker of TCS exposure.

\section{Methods of TCS analysis}

\section{Extraction methods}

The analysis of environmental pollutants at trace and ultratrace levels is a complex task and presents a real challenge (Wise et al. 2006). The protocols for TCS analysis in various matrices involve different sample preparation methods (Table 1). One of the key challenges in the development of reliable preconcentration step is the hydrophobic nature of TCS and the fact that TCS is usually present in a complex mixture with a great number of pollutants and degradation products.

A rapid and economic enzyme-linked immunosorbent assay (ELISA) together with the different types of ecofriendly microextraction techniques has been developed in recent years for monitoring of TCS exposure such as air-assisted liquid-liquid microextraction (AALLME), microextraction by packed sorbent (MEPS), stir bar sorptive extraction (SBSE) and vortex assisted-supramolecular solvent-based microextraction (VA-SSME) (Ahn et al. 2012; González-Mariño et al. 2011; Mpupa et al. 2017; Rocha et al. 2019).

However, liquid/liquid extraction (LLE) and solid-phase extraction (SPE) are still the most popular methods for the separation and enrichment of TCS before further analysis. High TCS recoveries at low concentrations can still be met for surface water, groundwater and even drinking water (Table 1). LLE involves large quantities of organic solvents (hexane, dichloromethane, etc.), whereas C18 and HLB cartridges are needed for the SPE technique (González-Mariño et al. 2011). Both extraction methods can cause loss of tracelevel analyte due to the multi-step procedure (Arditsoglou and Voutsa 2008; Gatidou et al. 2007; Li et al. 2010, 2013; Pirard et al. 2012; Schebb et al. 2011).

To tackle TCS in air and soil samples, pressure liquid extraction (PLE) and accelerated solvent extraction (ASE) can be used (Cha and Cupples 2009; Laborie et al. 2016; Kinney et al. 2008). Ultrasonic extraction and the combination of microwave-assisted extraction with SPE are reliable techniques in TCS sediment analysis (Azzouz and Ballesteros 2016; Juksu et al. 2019; Chen et al. 2020). Soxhlet 
extraction and SPE (QuEChERS) can also be applied for TCS extraction from biota (Bai and Acharya 2019; Das Sarkar et al. 2020; Juksu et al. 2019; Yao et al. 2019).

In order to determine the total TCS (free and conjugated) in urine samples, the incubation with $\beta$-glucuronidase and sulfatase enzymes must be performed, prior to the extraction process (Moos et al. 2014; Sandborgh-Englund et al. 2006). Again, SPE is mostly used as preconcentration step prior the further chromatographic analysis. Urine is generally accepted as the matrix of choice for biomonitoring to the TCS exposure, while other biological fluids, such as blood, breast milk and amniotic fluid, are rarely used (Azzouz et al. 2016; Iyer et al. 2018; Shekhar et al. 2017). The cumulative exposure to TCS could be evaluated by analysis of human nails (Shi et al. 2013).

\section{Analytical methods}

In last decade, owing to the great improvements in instrumentalization, the detection of TCS in water samples is even possible in $10^{-4} \mathrm{nM}$ concentrations (Table 1). Classical high-performance liquid chromatography (HPLC) coupled with visible (VIS), ultraviolet (UV) or diode array detector can be unable to fulfill the required limit of the detection (LOD) and quantification (LOQ) both in environmental and biological samples.

Actually, chromatography coupled with mass spectrometry (GC-MS) allows the routine detection of TCS in different samples (Table 1). After the extraction, a derivatization step is required for GC-MS analysis due to the TCS low volatility. The substances like 2,3,4,5,6-pentafluorobenzyl bromide, pentafluorobenzoyl chloride ( $\mathrm{PFBCl}$ ), N,O-bis (trimethylsilyl) trifluoroacetamide (BSTFA), trimethylchlorosilane (TMCS) and pyridine are commonly used as derivatization agents (Azzouz et al. 2016; Gatidou et al. 2007; Geens et al. 2009b; Provencher et al. 2014).

Liquid chromatography coupled with mass spectrometry (LC-MS) or tandem mass spectrometry (LC-MS/MS) equipped with $\mathrm{C} 8$ or $\mathrm{C} 18$ column are commonly applied for the development of rapid and sensitive analytical methods (Table 1). Particularly, the tandem MS ensures selective TCS detection and high sensitivity even at $\mathrm{pM}$ level. Considering the fact that TCS levels in groundwater are expected to be low, time of flight (TOF-MS) detector can meet fM level sensitivity (Table 1) (Pintado-Herrera et al. 2014). Although current analytical method is reliable and sensitive, the overall processes are still complex and expensive.

In spite of the significant improvement in the TCS analysis, the development of an appropriate, simple and inexpensive technique to monitor TCS regularly still presents a real analytical challenge due to the high lipophilicity of TCS, complexity of matrices and low concentrations.

\section{Possible adverse effects of TCS}

\section{In vitro analyses}

Bearing in mind the TCS properties, the exposure routes and ubiquitous occurrence in the environment, several in vitro toxicity screenings were conducted. The summarized findings are presented in Table 2.

The TCS exposure caused a significant hippocampal neuronal function damage and was related to the decreased long-term memory formation (Arias-Cavieres et al. 2018), while based on murine cardiac skeletal muscle cell experiments TCS led to the dysregulation of excitation-contraction coupling, which could result in serious complications such as heart failure and arrhythmias (Cherednichenko et al. 2012).

TCS acts as estrogenic agonist and antagonist based on the experiments conducted on various breast cancer cells (Huang et al. 2014b; Henry and Fair 2013). Thus, antagonist effects of TCS were also observed on glucocorticoid, androgenic and thyroid receptors (Kenda et al. 2020). Different mechanisms of in vitro disruption of thyroid homeostasis were suggested such as dose-response inhibition of $\mathrm{T} 4$ to T3 conversion (Butt et al. 2011) as well as a non-competitive inhibition of iodide uptake in rat thyroid follicular cells and thyroid peroxidase activity in rat microsomes ( $\mathrm{Wu}$ et al. 2016).

TCS impact on early embryonic development (Kim et al. 2020), particularly on rodent neurons, was recently studied (Szychowski et al. 2015, 2019; Tran et al. 2020). The disturbed differentiation and development of various stem cells were observed (Cheng et al. 2019; Guo et al. 2012; Park et al. 2016). The observed developmental toxicity was the consequence of different apoptotic processes. The mechanisms include morphological and functional changes of mitochondria with the increased production of reactive oxygen species (ROS). Oxidative stress was also related to the human thyroid follicular epithelial cell toxicity (Zhang et al. 2018) and to the observed effects on primary human keratinocytes, NIH-3T3 mouse fibroblasts and RBL-2H3 mast cells (Weatherly et al. 2018).

Today, there is a rising concern that the everyday exposure to TCS and related compounds in personal care products potentially increase the risk of cancer incidence. In this regard, TCS could increase proliferation, migration and invasion of human prostate cancer cells (Kim et al. 2015), human lung carcinoma cells (Winitthana et al. 2014) and both estrogen positive and estrogen negative human breast cancer cells (Farasani and Darbre 2020; Lee et al. 2014). $\mathrm{Wu}$ et al. (2015) also observed the proliferation of mouse epidermis-derived cells. These findings are worrying since the consumption of certain hygiene products leads to the 
Table 2 In vitro triclosan toxicity

\begin{tabular}{|c|c|c|c|}
\hline Experimental model & TCS dose & Effects & Reference \\
\hline $\begin{array}{l}\text { Hippocampal slices from male rats, } \\
\text { hippocampal cell cultures from the } \\
\text { rat embryos }\end{array}$ & 1,5 and $10 \mu \mathrm{M}$ & $\downarrow$ Hippocampal neuronal functions & Arias-Cavieres et al. (2018) \\
\hline $\begin{array}{l}\text { Neural stem cells from Sprague } \\
\text { Dawley rat embryos }\end{array}$ & 1 to $50 \mu \mathrm{M}$ & $\begin{array}{l}\uparrow \text { Neurodegenerative effects } \uparrow \text { ROS activa- } \\
\text { tion } \\
\uparrow \text { Apoptosis }\end{array}$ & Park et al. (2016) \\
\hline \multirow{2}{*}{$\begin{array}{l}\text { Cortical neurons from mouse } \\
\text { embryos }\end{array}$} & $1 \mathrm{nM}$ to $100 \mu \mathrm{M}$ & $\uparrow$ Apoptosis & Szychowski et al. (2015) \\
\hline & $0.01 \mu \mathrm{M}$ and $1 \mu \mathrm{M}$ & $\begin{array}{l}\downarrow \text { Proliferation } \\
\uparrow \text { Apoptosis }\end{array}$ & Tran et al. (2020) \\
\hline $\begin{array}{l}\text { Mouse neocortical neurons from } \\
\text { fetuses of pregnant female Swiss } \\
\text { mice }\end{array}$ & $10 \mu \mathrm{M}$ & $\begin{array}{l}\uparrow \text { Neurotoxicity via NMDAR activation } \\
\uparrow \text { ROS production } \\
\uparrow \text { LDH release } \\
\uparrow \text { Apoptosis }\end{array}$ & Szychowski et al. (2019) \\
\hline $\begin{array}{l}\text { Murine cardiac and skeletal muscle } \\
\text { cells }\end{array}$ & $0.5,1$ and $10 \mu \mathrm{M}$ & $\downarrow$ Excitation-contraction coupling & Cherednichenko et al. (2012) \\
\hline Human liver microsomes & $400 \mu \mathrm{M}\left(\mathrm{IC}_{50}\right)$ & $\downarrow$ T4 to T3 conversion & Butt et al. (2011) \\
\hline $\begin{array}{l}\text { FRTL-5 rat thyroid follicular cells, } \\
\text { rat thyroid microsomes }\end{array}$ & $\begin{array}{l}21.3 \mu \mathrm{M} \text { (inhibition constant } \\
\left.\mathrm{K}_{\mathrm{i}}\right), 165.8 \mu \mathrm{M}\left(\mathrm{IC}_{50}\right)\end{array}$ & $\begin{array}{l}\downarrow \text { Sodium/iodide symporter-mediated } \\
\text { iodide uptake } \\
\downarrow \text { Thyroid peroxidase activity }\end{array}$ & Wu et al. (2016) \\
\hline $\begin{array}{l}\text { Nthy-ori 3-1 human thyroid follicu- } \\
\text { lar epithelial cells }\end{array}$ & $10 \mu \mathrm{M}$ & $\begin{array}{l}\uparrow \text { Oxidative stress and ROS production } \\
\downarrow \text { Viability } \\
\uparrow \text { p38 pathway }\end{array}$ & Zhang et al. (2018) \\
\hline $\begin{array}{l}\text { GH3.TRE-Luc thyroid-responsive } \\
\text { rat pituitary tumor cells }\end{array}$ & 5 and $10 \mu \mathrm{M}$ & Thyroid receptor antagonist & Kenda et al. (2020) \\
\hline $\begin{array}{l}\text { GH3 rat pituitary somatolacto- } \\
\text { trophic cell line }\end{array}$ & $10^{-3}, 0.1$ and $10 \mu \mathrm{M}$ & $\begin{array}{l}\uparrow \text { CaBP-9 k mRNA and protein estrogenic } \\
\text { activity via ER-dependent pathway }\end{array}$ & Jung et al. (2012) \\
\hline \multirow[t]{3}{*}{ MCF-7 } & $0.1 \mu \mathrm{M}$ & $\uparrow$ Migration and invasion & Farasani and Darbre (2020) \\
\hline & 0.1 to $10 \mu \mathrm{M}$ & $\begin{array}{l}\uparrow \text { Cell growth via ER-mediated signaling } \\
\text { pathway } \\
\uparrow \text { Cyclin D1 expression } \\
\downarrow \text { p21 expression }\end{array}$ & Lee et al. (2014) \\
\hline & $10^{-3}$ to $1 \mu \mathrm{M}$ & Estrogenic effect & Huang et al. (2014b) \\
\hline MCF-7 BOS & 0.007 to $691 \mathrm{mM}$ & Estrogenic and anti-estrogenic & Henry and Fair (2013) \\
\hline MCF-10F, MDA-MB-231 & $0.1 \mu \mathrm{M}$ & $\uparrow$ Migration and invasion & Farasani and Darbre (2020) \\
\hline MDA-kb2 & 5 and $10 \mu \mathrm{M}$ & $\begin{array}{l}\text { Glucocorticoid, estrogenic, androgenic, } \\
\text { thyroid receptor antagonist }\end{array}$ & Kenda et al. (2020) \\
\hline $\begin{array}{l}\text { AR-EcoScreen hamster ovary cell } \\
\text { line cells, hERa-HeLa-9903 }\end{array}$ & 5 and $10 \mu \mathrm{M}$ & $\begin{array}{l}\text { Androgen receptor antagonist Estrogen } \\
\text { receptor antagonist }\end{array}$ & Kenda et al. (2020) \\
\hline $\begin{array}{l}\text { CV-1 African green monkey kidney } \\
\text { cells }\end{array}$ & $10^{-3}$ to $1 \mu \mathrm{M}$ & Weak estrogenic effect & Huang et al. (2014b) \\
\hline $\begin{array}{l}\text { Primary human keratinocytes, NIH- } \\
3 \text { T3 mouse fibroblasts, RBL-2H3 } \\
\text { mast cells }\end{array}$ & 1 to $20 \mu \mathrm{M}$ & $\begin{array}{l}\uparrow \text { Morphological changes and } \\
\downarrow \text { Membrane potential of mitochondria } \\
\uparrow \text { ROS production Endoplasmic reticulum } \\
\text { and mitochondrial } \mathrm{Ca}^{2+} \text { levels alteration }\end{array}$ & Weatherly et al. (2018) \\
\hline $\begin{array}{l}\text { JB6 } \mathrm{Cl} 41-5 \text { a mouse epidermis- } \\
\text { derived cells }\end{array}$ & 0.01 to $100 \mu \mathrm{M}$ & $\uparrow$ Proliferation & Wu et al. (2015) \\
\hline Human mesenchymal stem cells & 0.156 to $2.5 \mu \mathrm{M}$ & $\downarrow$ Adipocyte differentiation & Guo et al. (2012) \\
\hline Porcine oocytes & 1,10 and $100 \mu \mathrm{M}$ & $\begin{array}{l}\downarrow \text { Meiotic maturation and cumulus cell } \\
\text { expansion } \\
\uparrow \text { Mitochondrial superoxide levels and } \\
\text { mediated apoptosis }\end{array}$ & Park et al. (2020) \\
\hline Porcine parthenogenetic embryos & 50 and $100 \mu \mathrm{M}$ & $\begin{array}{l}\downarrow \text { Early embryonic development } \\
\uparrow \text { ROD-related oxidative stress } \\
\uparrow \text { Mitochondrial dysfunction }\end{array}$ & Kim et al. (2020) \\
\hline
\end{tabular}


Table 2 (continued)

\begin{tabular}{llll}
\hline Experimental model & TCS dose & Effects & Reference \\
\hline Mouse embryonic stem cells (ESCs) & $\begin{array}{l}1.7 \text { to } 138.1 \mu \mathrm{M} — \text { cardiac } \\
\text { differentiation, } 0.01 \text { to }\end{array}$ & $\downarrow$ Cardiac and osteogenic differentiation & Cheng et al. (2019) \\
& $\begin{array}{l}8.6 \mu \mathrm{M} — \text { osteogenic dif- } \\
\text { ferentiation }\end{array}$ & & \\
& 0.01 to $10 \mu \mathrm{M}$ & $\uparrow$ Proliferation and migration & Kim et al. (2015) \\
LNCaP & $2.5,5$ and $7.5 \mu \mathrm{M}$ & $\begin{array}{l}\uparrow \text { Growth, migration, invasion and survival } \\
\text { via the epithelial-to-mesenchymal transi- }\end{array}$ & \\
NCI-H460 & & tion process & \\
& & &
\end{tabular}

chronic daily exposure to TCS through the dermal route. However, it remains unanswered if the studied effect is relevant to humans (Wu et al. 2015).

\section{In vivo analyses}

Some of the toxicity mechanisms of TCS were confirmed in the in vivo studies on rodents (Table 3). Multiple neurodegenerative TCS effects were determined in mice and rats, including reduced spatial memory performance, anxiety-related behavior and reduced neuromuscular functions (Arias-Cavieres et al. 2018; Tabari et al. 2019). Neurobehavioral toxicity was also observed in the mice offspring after subcutaneous treatment with TCS (Tran et al. 2020).

Additionally, cardiovascular and skeletal muscle toxicity was also confirmed in vivo in mice (Cherednichenko et al. 2012). Regarding reproductive health, the placenta might be particularly susceptible to TCS accumulation and TCS-induced dysregulation of endocrine function (Feng et al. 2016). Endocrine disrupting properties of TCS were also examined in various animal models within a wide range of doses and dosing regimens, which makes the obtained results difficult to compare. For instance, administration of TCS in concentration up to $0.345 \mathrm{mmol} / \mathrm{kg} / \mathrm{day}$ resulted in a decrease of luteinizing hormone (LH) and follicle-stimulating hormone (FSH) in female mice (Cao et al. 2018), while at the higher oral dose $(0.639 \mathrm{mmol} /$ $\mathrm{kg}$ /day), increased both FSH and LH were measured in Sprague Dawley rats (Abd-Elhakim et al. 2018). However, a comparable reduction in thyroid hormones, T3 and T4, was observed in male Wistar albino rats (Taha et al. 2020), female Sprague Dawley rats (Abd-Elhakim et al. 2018) and female mice (Cao et al. 2018). The findings are in agreement with the in vitro data suggesting TCS hypothyroidism-inducing effects (Butt et al. 2011). The parameters of metabolic disorders, such as increased serum glucose and lipid levels, as well as morphological and functional liver changes were measured in TCS-treated rodents (Huang et al. 2020; Ma et al. 2020; Yang et al. 2015; Yueh et al. 2020). The conducted animal studies revealed that TCS possessed a certain hormonal activity, especially on female sex hormones. Furthermore, an endocrine receptor (ER)dependent signaling pathway of breast tumor growth in mice was proposed (Lee et al. 2014).

Considering the antimicrobial activity, TCS was also associated with the decreased gut microbiota diversity in treated animals (Yang et al. 2018; Yueh et al. 2020). Besides this fact, proinflammatory TCS potential was responsible for the adverse effects noticed on the pulmonary and digestive systems, liver and spleen (Mohammed et al. 2017; Yang et al. 2018). TCS impact on the immune system was recently studied by Shane and co-authors (Shane et al. 2020).

Although animal studies suggest that TCS represents a hazardous substance for different body systems and biochemical processes, epidemiological studies are needed to test the hypotheses.

\section{Epidemiological studies}

Most of the available epidemiological studies regarding the adverse effects of TCS are focused on developmental toxicity and involve women, or women-children's pairs (Table 4). This is reasonable due to the estrogen-dependent toxicity pathways observed in vitro and in vivo. In a prospective cohort study, gestational and childhood TCS concentrations were positively associated with hyperactivity, attention and behavior disorders (Jackson-Browne et al. 2019). Moreover, it was concluded that TCS prenatal exposure might affect the intelligence and academic performance of children of the ages 7 and 8 (Jackson-Browne et al. 2020; Tanner et al. 2020). Although ROS activation and apoptosis induction were observed in vitro in undeveloped neurons (Park et al. 2016), the mechanisms of this neurodevelopmental impairment related to TCS exposure were not clarified. The potential relationship between TCS exposure and the decreased cognitive functioning and induced hypothyroidism was suggested (Jackson-Browne et al. 2019), both in the in vivo and in vitro studies (Butt et al. 2011; Zhang et al. 2018). The thyroid hormone homeostasis could be particularly vulnerable to EDCs in pregnancy, and accordingly, an association 


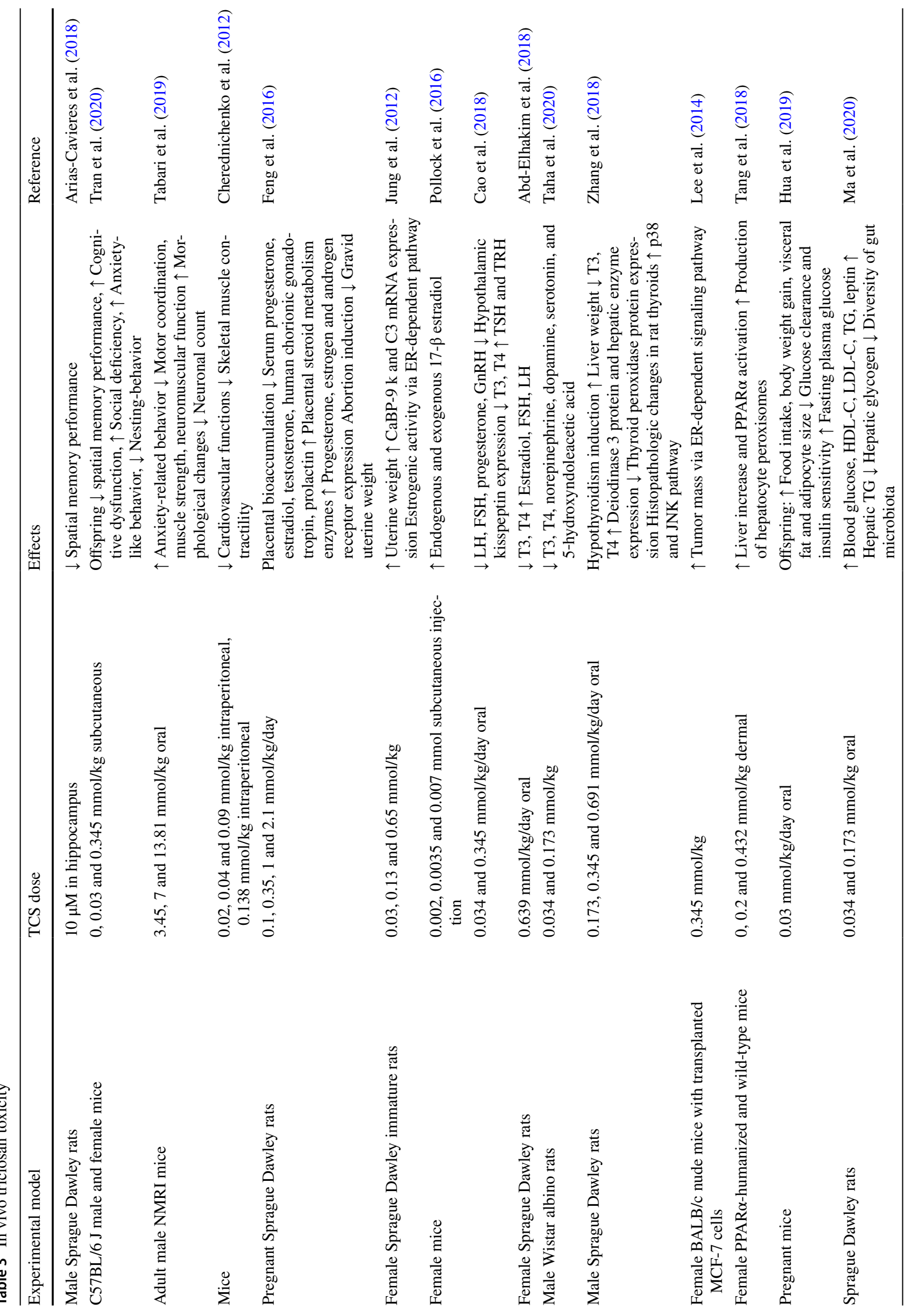




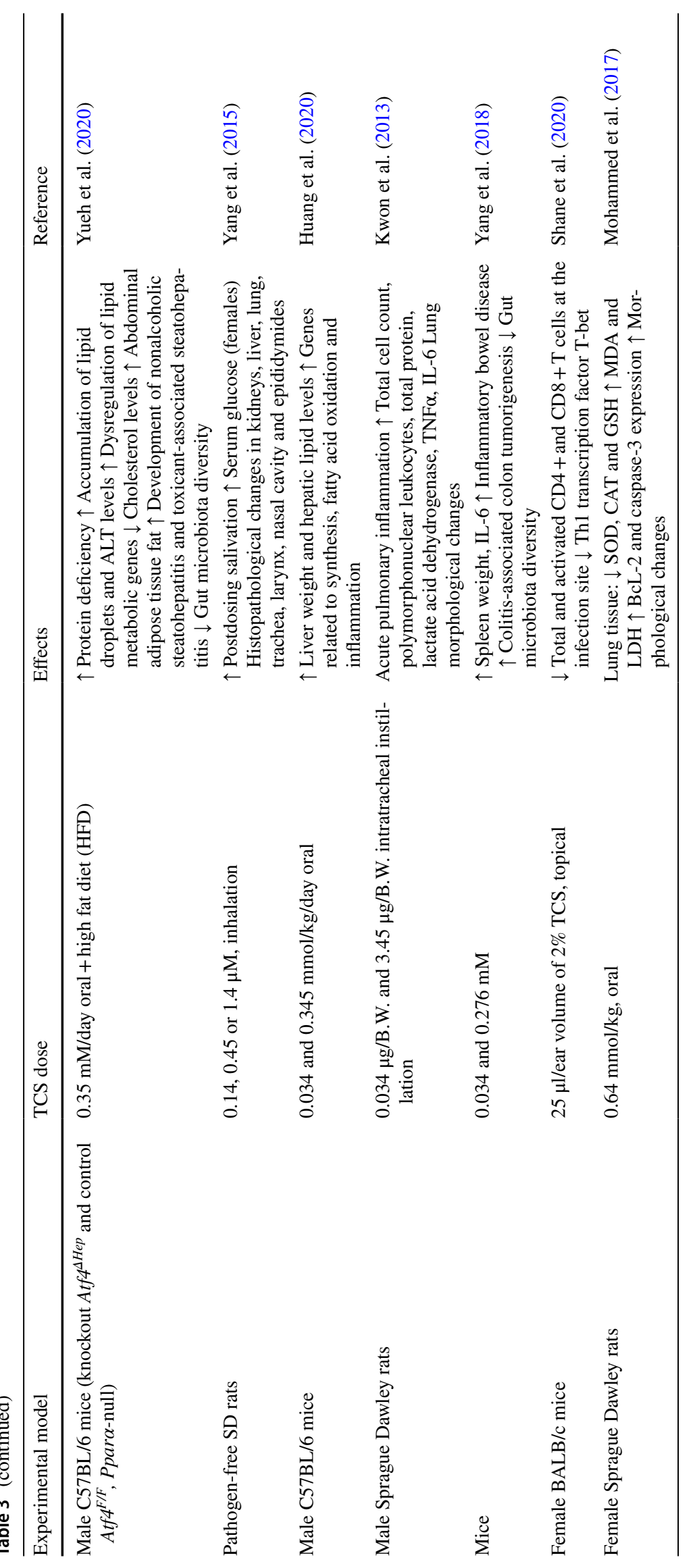




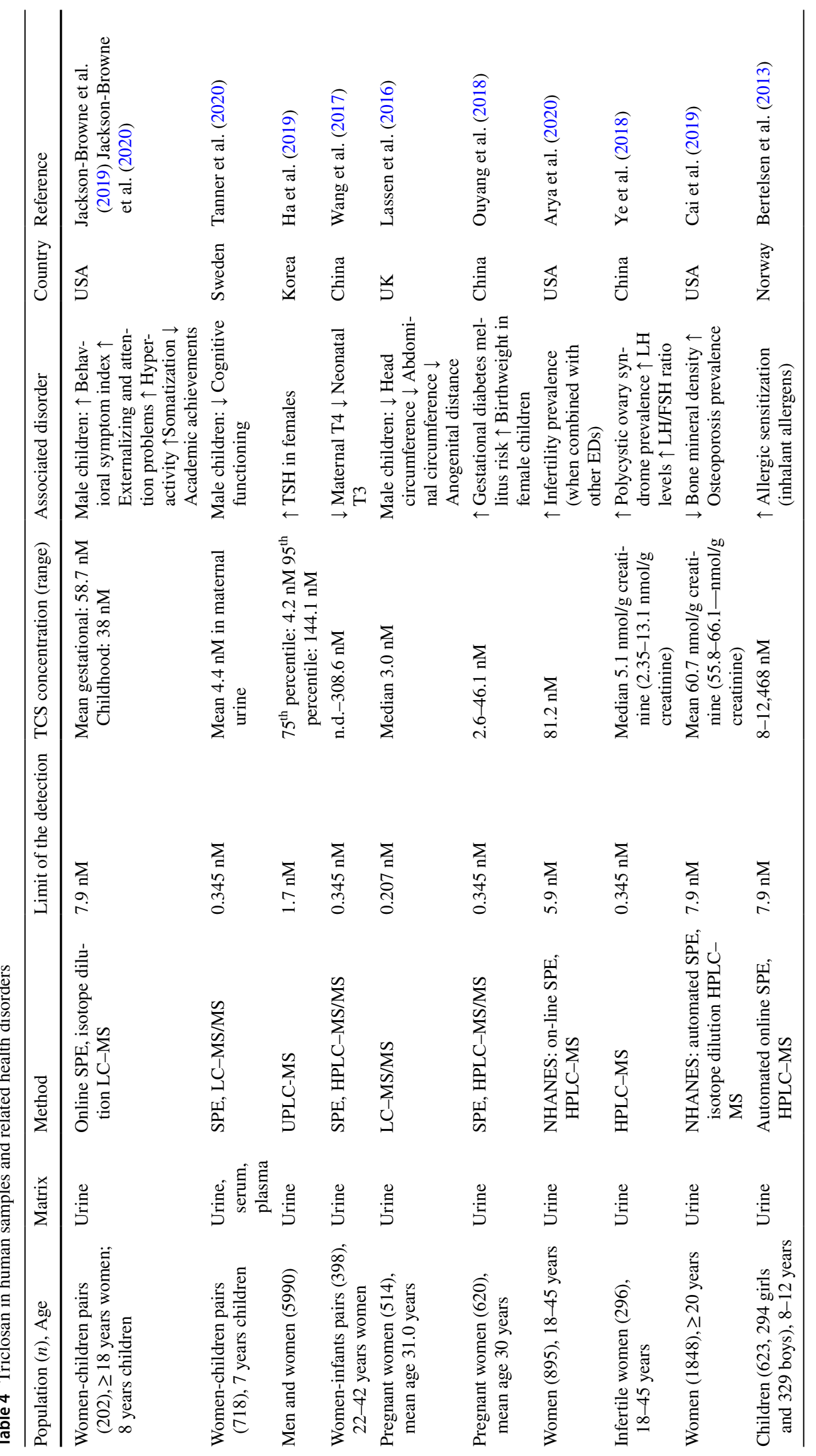


between lower maternal and neonatal thyroid hormones and maternal urinary TCS levels was also found in a prospective birth cohort study (Wang et al. 2017).

The increased TCS maternal urinary concentrations, as indicators of prenatal TCS exposure, were inversely associated with the anthropometric measures and anogenital distance in boys, with a borderline statistical significance, but not in girls waging to the anti-androgenic activity of TCS (Lassen et al. 2016). Another study, conducted on pregnant women of the Chinese urban cohort, observed the higher birth weight of female children, as well as the higher risk for development of gestation diabetes mellitus (GDM) (Ouyang et al. 2018). These effects could mainly be attributed to an increased maternal body mass index (BMI), but without statistical significance. Besides, insulin resistance and thyroidmediated metabolic effects could cause elevated GDM risk (Ouyang et al. 2018).

On the contrary, Huo and co-authors (2018) found relatively low TCS concentrations in the urine samples of pregnant Chinese women, with no consistent associations with birth outcomes (Huo et al. 2018). No association was found between impaired glucose metabolism in pregnant women (Shapiro et al. 2018), nor in a cross-sectional study involving men and women (Ward et al. 2020). With regard to these results, it is worth noting that the data regarding the association of TCS exposure with metabolic disorders are inconsistent and should be further investigated.

The prevalence of other endocrine-related disorders, specific to the female population: osteoporosis (tightly related to thyroid hormones and estrogen activity) and polycystic ovary syndrome (associated with the impaired glucose metabolism and women infertility) were also found to be increased in women with elevated TCS urinary levels (Cai et al. 2019; Ye et al. 2018).

In children, both girls and boys, TCS urinary levels were associated with allergic sensitization to inhalant allergens (Bertelsen et al. 2013). However, the molecular basis of this adverse effect was not investigated despite the high incidence rate of allergic reactions.

Having in mind the widespread exposure to TCS on daily basis, more epidemiological studies on a large number of participants of different age and health status are necessary in order to understand the underlying mechanism and the health problems associated with TCS.

\section{TCS and COVID-19}

The outbreak of COVID-19 disease set an important requirement to achieve the highest levels of hygiene, particularly hand hygiene (Rundle et al. 2020). Therefore, the increased use of antibacterial soaps and disinfectants during the
COVID-19 pandemic was followed with the increased exposure to TCS (Ejtahed et al. 2020; Usman et al. 2020). The non-alcohol-based sanitizers usually contain TCS instead of alcohol as antimicrobial or disinfecting agent (Atolani et al. 2020). TCS is a broad-spectrum antibacterial agent with antifungal effects. Interestingly, during the outbreak of severe acute respiratory syndrome (SARS) in 2003, it was determined that only $0.05 \%$ of TCS ensures 'at least a $3-\log$ reduction of the virus from the surface without any virus recovered in any of the wells within a 30-s contact time' (Dellanno et al. 2009). Consequently, it was believed that TCS poses virucidal efficacy also against SARS-CoV-2 strain (Ejtahed et al. 2020).

Full commitment to the principles of personal hygiene remains a major action for the prevention of transmission of SARS-CoV-2 virus. Apart from the fact that TCS induces Staphylococcus aureus and Escherichia coli resistance to antibiotics, the repeated exposure to TCS can also result in skin and gut microbiome alterations followed with the development of chronic disease (Ejtahed et al. 2020; Subramanya et al. 2021). In this context, if the harmful compound as TCS is present in personal care products, compliance with health recommendations can have negative impact to both human health and environment.

\section{Conclusion}

On the basis of the available literature data, it is high time to consider TCS as a rapidly growing environmental issue, especially now during the COVID-19 pandemic when the high level of sanitation and personal hygiene is constantly required. Despite the TCS antibacterial and antifungal effects as well as suggested virucidal efficacy against SARS-CoV-2 strain, the alarming results about the negative consequences of the permanent exposure to low TCS levels should strengthen the critical revision of current international standards regarding TCS and necessitate the establishment of the stricter measures at worldwide scale. However, the awareness among the policy-makers and stakeholders is still lacking. Further follow-up studies conducted on a large number of participants will expand the current knowledge about the TCS-induced health effects. The reevaluation and harmonization of current legislation regarding the utilization of TCS in different products are of high demand together with the new prioritization methodology which will consider TCS as a priority substance included in the regular monitoring programs worldwide. Both environmental and health risks associated with TCS cannot be reduced without proper management and full commitment to adequate legislation in compliance with the environmental protection in order to obtain a good ecological status. 
Author contribution MM: conceptualization, visualization, resources, writing original draft preparation; LĐ: resources, writing original draft preparation; NM: visualization, writing-reviewing and editing; NM: conceptualization, writing — reviewing and editing, supervision.

Availability of data and materials The datasets used and/or analyzed during the current study are available from the corresponding author on reasonable request.

\section{Declarations}

Ethics approval and consent to participate Not applicable.

Consent for publication All authors agree with the content and have given their explicit consent to submit the paper.

Competing interests The authors declare no competing interests.

\section{References}

Abd-Elhakim YM, Mohammed AT, Ali HA (2018) Impact of subchronic exposure to triclosan and/or fluoride on estrogenic activity in immature female rats: the expression pattern of calbindin-D9k and estrogen receptor $\alpha$ genes. J Biochem Mol Toxicol 32(2). https://doi.org/10.1002/jbt.22027

Adithya S, Jayaraman RS, Krishnan A, Malolan R, Gopinath KP, Arun J, Kim W, Govarthanan M (2021) A critical review on the formation, fate and degradation of the persistent organic pollutant hexachlorocyclohexane in water systems and waste streams. Chemosphere 271:129866. https://doi.org/10.1016/j.chemosphere. 2021.129866

Ahn KC, Kasagami T, Tsai HJ, Schebb NH, Ogunyoku T, Gee SJ, Young TM, Hammock BD (2012) An immunoassay to evaluate human/environmental exposure to the antimicrobial triclocarban. Environ Sci Technol 46(1):374-381. https://doi.org/10. $1021 /$ es202494d

Alfhili MA, Lee MH (2019) Triclosan: an update on biochemical and molecular mechanisms. Oxid Med Cell Longev 2019:1607304. https://doi.org/10.1155/2019/1607304

Aranami K, Readman JW (2007) Photolytic degradation of triclosan in freshwater and seawater. Chemosphere 66(6):1052-1056. https:// doi.org/10.1016/j.chemosphere.2006.07.010

Arditsoglou A, Voutsa D (2008) Determination of phenolic and steroid endocrine disrupting compounds in environmental matrices. Environ Sci Pollut Res Int 15(3):228-236. https://doi.org/10. 1065/espr2007.12.459

Arias-Cavieres A, More J, Vicente JM, Adasme T, Hidalgo J, Valdés JL, Humeres A, Valdés-Undurraga I, Sánchez G, Hidalgo C, Barrientos G (2018) Triclosan impairs hippocampal synaptic plasticity and spatial memory in male rats. Front Mol Neurosci 11:429. https://doi.org/10.3389/fnmol.2018.00429

Arya S, Dwivedi AK, Alvarado L, Kupesic-Plavsic S (2020) Exposure of U.S. population to endocrine disruptive chemicals (Parabens, Benzophenone-3, Bisphenol-A and Triclosan) and their associations with female infertility. Environ Pollut 265(Pt A):114763. https://doi.org/10.1016/j.envpol.2020.114763

Atolani O, Baker MT, Adeyemi OS, Olanrewaju IR, Hamid AA, Ameen OM, Oguntoye SO, Usman LA (2020) COVID-19: critical discussion on the applications and implications of chemicals in sanitizers and disinfectants. EXCLI J 19:785-799. https://doi. org/10.17179/excli2020-2349
Azzouz A, Ballesteros E (2016) Determination of 13 endocrine disrupting chemicals in environmental solid samples using microwave-assisted solvent extraction and continuous solid-phase extraction followed by gas chromatography-mass spectrometry. Anal Bioanal Chem 408(1):231-241. https://doi.org/10.1007/ s00216-015-9096-1

Azzouz A, Rascón AJ, Ballesteros E (2016) Simultaneous determination of parabens, alkylphenols, phenylphenols, bisphenol A and triclosan in human urine, blood and breast milk by continuous solid-phase extraction and gas chromatography-mass spectrometry. J Pharm Biomed Anal 119:16-26. https://doi.org/10.1016/j. jpba.2015.11.024

Bai X, Acharya K (2019) Uptake of endocrine-disrupting chemicals by quagga mussels (Dreissena bugensis) in an urban-impacted aquatic ecosystem. Environ Sci Pollut Res Int 26(1):250-258. https://doi.org/10.1007/s11356-018-3320-4

Bedoux G, Roig B, Thomas O, Dupont V, Le Bot B (2012) Occurrence and toxicity of antimicrobial triclosan and by-products in the environment. Environ Sci Pollut Res Int 19(4):1044-1065. https://doi.org/10.1007/s11356-011-0632-z

Bertelsen RJ, Longnecker MP, Løvik M, Calafat AM, Carlsen KH, London SJ, Lødrup Carlsen KC (2013) Triclosan exposure and allergic sensitization in Norwegian children. Allergy 68(1):8491. https://doi.org/10.1111/all.12058

Butt CM, Wang D, Stapleton HM (2011) Halogenated phenolic contaminants inhibit the in vitro activity of the thyroid-regulating deiodinases in human liver. Toxicol Sci 124(2):339-347. https:// doi.org/10.1093/toxsci/kfr117

Cai S, Zhu J, Sun L, Fan C, Zhong Y, Shen Q, Li Y (2019) Association between urinary triclosan with bone mass density and osteoporosis in US adult women, 2005-2010. J Clin Endocrinol Metab 104(10):4531-4538. https://doi.org/10.1210/jc.2019-00576

Calderon-Preciado D, Renault Q, Matamoros V, Canameras N, Bayona JM (2012) Uptake of organic emergent contaminants in spath and lettuce: an in vitro experiment. J Agric Food Chem 60:2000 2007. https://doi.org/10.1021/jf2046224

Cao XY, Hua X, Xiong JW, Zhu WT, Zhang J, Chen L (2018) Impact of triclosan on female reproduction through reducing thyroid hormones to suppress hypothalamic kisspeptin neurons in mice. Front Mol Neurosci 11:6. https://doi.org/10.3389/fnmol.2018. 00006

Carvalho RN, Marinov D, Loos R, Napierska D, Chirico N, Lettieri T (2016) Monitoring-based exercise: second review of the priority substances list under the Water Framework Directive. JRC Sci Policy Rep (Draft). https://circabc.europa.eu/sd/a/7fe29322-946a4ead-b3b9-e3b156d0c318/Monitoring-based\%20Exercise\%20Rep ort_FINAL\%20DRAFT_25nov2016.pdf Accessed 5th Jan 2021

Cha J, Cupples AM (2009) Detection of the antimicrobials triclocarban and triclosan in agricultural soils following land application of municipal biosolids. Water Res 43:2522-2530. https://doi.org/ 10.1016/j.watres.2009.03.004

Chen L, Wang Z, Jing Z, Wang Z, Cao S, Yu T (2015) Accumulation and risk of triclosan in surface sediments near the outfalls of municipal wastewater treatment plants. Bull Environ Contam Toxicol 95(4):525-529. https://doi.org/10.1007/ s00128-015-1630-5

Chen ZF, Wen HB, Dai X, Yan SC, Zhang H, Chen YY, Du Z, Liu G, Cai Z (2020) Contamination and risk profiles of triclosan and triclocarban in sediments from a less urbanized region in China. J Hazard Mater 357:376-383. https://doi.org/10.1016/j.jhazmat. 2018.06.020

Cheng W, Yang S, Liang F, Wang W, Zhou R, Li Y, Feng Y, Wang Y (2019) Low-dose exposure to triclosan disrupted osteogenic differentiation of mouse embryonic stem cells via BMP/ERK/ Smad/Runx-2 signalling pathway. Food Chem Toxicol 127:1-10. https://doi.org/10.1016/j.fct.2019.02.038 
Cherednichenko G, Zhang R, Bannister RA, Timofeyev V, Li N, Fritsch EB, Feng W, Barrientos GC, Schebb NH, Hammock BD, Beam KG, Chiamvimonvat N, Pessah IN (2012) Triclosan impairs excitation-contraction coupling and $\mathrm{Ca} 2+$ dynamics in striated muscle. Proc Natl Acad Sci USA 109(35):14158-14163. https:// doi.org/10.1073/pnas.1211314109

Chu W, Fang C, Deng Y, Xu Z (2020) Intensified disinfection amid COVID-19 pandemic poses potential risks to water quality and safety. Environ Sci Technol 55(7):4084-4086. https://doi.org/10. 1021/acs.est.0c04394

Cosmetic Ingredient Review (CIR) (2010) Final Report Triclosan. http://www.cir-safety.org/sites/default/files/FR569.pdf Accessed 5th Jan 2021

Das Sarkar S, Nag SK, Kumari K, Saha K, Bandyopadhyay S, Aftabuddin M (2020) Das BK (2020) Occurrence and safety evaluation of antimicrobial compounds triclosan and triclocarban in water and fishes of the multitrophic niche of River Torsa. India Arch Environ Contam Toxicol 79(4):488-499. https://doi.org/10.1007/ s00244-020-00785-0

Dellanno C, Vega Q, Boesenberg D (2009) The antiviral action of common household disinfectants and antiseptics against murine hepatitis virus, a potential surrogate for SARS coronavirus. Am J Infect Control 37(8):649-652. https://doi.org/10.1016/j.ajic. 2009.03.012

Dhama K, Patel SK, Kumar R, Masand R, Rana J, Yatoo MI, Tiwari R, Sharun K, Mohapatra RK, Natesan S, Dhawan M, Ahmad T, Emran TB, Malik YS, Harapan H (2021) The role of disinfectants and sanitizers during COVID-19 pandemic: advantages and deleterious effects on humans and the environment. Environ Sci Pollut Res Int 28(26):34211-34228. https://doi.org/10.1007/ s11356-021-14429-w

Dhillon GS, Kaur S, Pulicharla R, Brar SK, Cledón M, Verma M, Surampalli RY (2015) Triclosan: current status, occurrence, environmental risks and bioaccumulation potential. Int J Environ Res Public Health 12(5):5657-5684. https://doi.org/10.3390/ ijerph120505657

Ejtahed HS, Hasani-Ranjbar S, Siadat SD, Larijani B (2020) The most important challenges ahead of microbiome pattern in the post era of the COVID-19 pandemic. J Diabetes Metab Disord 19(2):1-3. https://doi.org/10.1007/s40200-020-00579-0

Esteban S, Gorga M, Petrovic M, González-Alonso S, Barceló D, Valcárcel Y (2014) Analysis and occurrence of endocrine-disrupting compounds and estrogenic activity in the surface waters of Central Spain. Sci Total Environ 466-467:939-951. https://doi.org/ 10.1016/j.scitotenv.2013.07.101

European Chemical Agency (ECHA) (2020) Substance Infocard, Triclosan. https://echa.europa.eu/substance-information/-/substancei nfo/100.020.167 Accessed 10th Jan 2021

European Commission (2020) Fitness check on endocrine disruptors. Commission Staff Working document. SWD (2020) 251 final. https://ec.europa.eu/environment/pdf/chemicals/2020/10/SWD_ on_Endocrines_disruptors.pdf. Accessed 10 Jan 2021

Fang JL, Stingley RL, Beland FA, Harrouk W, Lumpkins DL, Howard P (2010) Occurrence, efficacy, metabolism, and toxicity of triclosan. J Environ Sci Health C Environ Carcinog Ecotoxicol Rev 28(3):147-171. https://doi.org/10.1080/10590501.2010.504978

Farasani A, Darbre PD (2020) Long-term exposure to triclosan increases migration and invasion of human breast epithelial cells in vitro. J Appl Toxicol. https://doi.org/10.1002/jat.4097

Feng Y, Zhang P, Zhang Z, Shi J, Jiao Z, Shao B (2016) Endocrine disrupting effects of triclosan on the placenta in pregnant rats. PLoS ONE 11(5):e0154758. https://doi.org/10.1371/journal. pone. 0154758

Food and Drug Administration (FDA) (2016) Safety and effectiveness of consumer antiseptics; topical antimicrobial drug products for over-the-counter human use. https://www.federalregister.gov/ documents/2016/09/06/2016-21337/safety-and-effectivenessof-consumer-antiseptics-topical-antimicrobial-drug-products-for Accessed 5th Jan2021

Fu Q, Sanganyado E, Ye Q, Gan J (2016) Meta-analysis of biosolid effects on persistence of triclosan and triclocarban in soil. Environ Pollut 210:137-144. https://doi.org/10.1016/j.envpol.2015. 12.003

Gao CJ, Jia LL, Guo Y (2018) Triclosan in over the counter medicines of South China. Environ Monit Assess 190(12):728. https://doi. org/10.1007/s10661-018-7111-7

Gao H, Zhang C, Tao FB (2021) Association between prenatal phthalate exposure and gestational metabolic syndrome parameters: a systematic review of epidemiological studies. Environ Sci Pollut Res Int 28(17):20921-20938. https://doi.org/10.1007/ s11356-021-13120-4

Gangadharan P, Veetil P, Bhaskaran K, Bhasi A, Khan S, Bhaskaran K (2012) Degradation of triclosan under aerobic, anoxic, and anaerobic conditions. Appl Biochem Biotechnol 167:1603-1612. https://doi.org/10.1007/s12010-012-9573-3

Gatidou G, Thomaidis NS, Stasinakis AS, Lekkas TD (2007) Simultaneous determination of the endocrine disrupting compounds nonylphenol, nonylphenol ethoxylates, triclosan and bisphenol $\mathrm{A}$ in wastewater and sewage sludge by gas chromatography-mass spectrometry. J Chromatogr A 1138(1-2):32-41. https://doi.org/ 10.1016/j.chroma.2006.10.037

Geens T, Roosens L, Neels H, Covaci A (2009a) Assessment of human exposure to Bisphenol-A, Triclosan and Tetrabromobisphenol-A through indoor dust intake in Belgium. Chemosphere 76(6):755760. https://doi.org/10.1016/j.chemosphere.2009.05.024

Geens T, Neels H, Covaci A (2009b) Sensitive and selective method for the determination of bisphenol-A and triclosan in serum and urine as pentafluorobenzoate-derivatives using GC-ECNI/MS. J Chromatogr B Analyt Technol Biomed Life Sci 877(31):40424046. https://doi.org/10.1016/j.jchromb.2009.10.017

González-Mariño I, Quintana JB, Rodríguez I, Schrader S, Moeder M (2011) Fully automated determination of parabens, triclosan and methyl triclosan in wastewater by microextraction by packed sorbents and gas chromatography-mass spectrometry. Anal Chim Acta 684(1-2):50-57. https://doi.org/10.1016/j.aca.2010.10.049

Guesmi A, Sleno L (2020) In vitro metabolism of triclosan studied by liquid chromatography-high-resolution tandem mass spectrometry. Anal Bioanal Chem 412(2):335-342. https://doi.org/10. 1007/s00216-019-02239-6

Guo LW, Wu Q, Green B, Nolen G, Shi L, Losurdo J, Deng H, Bauer S, Fang JL, Ning B (2012) Cytotoxicity and inhibitory effects of low-concentration triclosan on adipogenic differentiation of human mesenchymal stem cells. Toxicol Appl Pharmacol 262(2):117-123. https://doi.org/10.1016/j.taap.2012.04.024

Ha NY, Kim DH, Ryu JY (2019) Relationship between triclosan exposure and thyroid hormones: the Second Korean National Environmental Health Survey (2012-2014). Ann Occup Environ Med 31:e22. https://doi.org/10.35371/aoem.2019.31.e22

Hippargi G, Anjankar S, Krupadam RJ, Rayalu SS (2021) Simultaneous wastewater treatment and generation of blended fuel methane and hydrogen using $\mathrm{Au}-\mathrm{Pt} / \mathrm{TiO} 2$ photo-reforming catalytic material. Fuel 291:120113. https://doi.org/10.1016/j.fuel.2020. 120113

Henry ND, Fair PA (2013) Comparison of in vitro cytotoxicity, estrogenicity and anti-estrogenicity of triclosan, perfluorooctane sulfonate and perfluorooctanoic acid. J Appl Toxicol 33(4):265272. https://doi.org/10.1002/jat.1736

Hua X, Xiong JW, Zhang YJ, Cao XY, Sun P, Wu J, Chen L (2019) Exposure of pregnant mice to triclosan causes hyperphagic obesity of offspring via the hypermethylation of proopiomelanocortin promoter. Arch Toxicol 93(2):547-558. https://doi.org/10. 1007/s00204-018-2338-1 
Huang CL, Ma HW, Yu CP (2014a) Substance flow analysis and assessment of environmental exposure potential for triclosan in mainland China. Sci Total Environ 499:265-275. https://doi.org/ 10.1016/j.scitotenv.2014.08.032

Huang H, Du G, Zhang W, Hu J, Wu D, Song L, Xia Y, Wang X (2014b) The in vitro estrogenic activities of triclosan and triclocarban. J Appl Toxicol 34(9):1060-1067. https://doi.org/10. $1002 /$ jat.3012

Huang W, Xie P, Cai Z (2020) Lipid metabolism disorders contribute to hepatotoxicity of triclosan in mice. J Hazard Mater 384:121310. https://doi.org/10.1016/j.jhazmat.2019.121310

Huo W, Xia W, Wu C, Zhu Y, Zhang B, Wan Y, Zhou A, Qian Z, Chen Z, Jiang Y, Liu H, Hu J, Xu B, Xu S, Li Y (2018) Urinary level of triclosan in a population of Chinese pregnant women and its association with birth outcomes. Environ Pollut 233:872-879. https://doi.org/10.1016/j.envpol.2017.08.073

Iyer AP, Xue J, Honda M, Robinson M, Kumosani TA, Abulnaja K, Kannan K (2018) Urinary levels of triclosan and triclocarban in several Asian countries, Greece and the USA: Association with oxidative stress. Environ Res 160:91-96. https://doi.org/ 10.1016/j.envres.2017.09.021

Jackson-Browne MS, Papandonatos GD, Chen A, Calafat AM, Yolton K, Lanphear BP, Braun JM (2020) Gestational and childhood urinary triclosan concentrations and academic achievement among 8-year-old children. Neurotoxicology 78:170-176. https://doi. org/10.1016/j.neuro.2020.03.011

Jackson-Browne MS, Papandonatos GD, Chen A, Yolton K, Lanphear BP, Braun JM (2019) Early-life triclosan exposure and parentreported behavior problems in 8-year-old children. Environ Int 128:446-456. https://doi.org/10.1016/j.envint.2019.01.021

Jagini S, Konda S, Bhagawan D, Himabindu V (2019) Emerging contaminant (triclosan) identification and its treatment: a review. SN Appl Sci 1:640. https://doi.org/10.1007/s42452-019-0634-x

Juksu K, Zhao JL, Liu YS, Yao L, Sarin C, Sreesai S, Klomjek P, Jiang YX, Ying GG (2019) Occurrence, fate and risk assessment of biocides in wastewater treatment plants and aquatic environments in Thailand. Sci Total Environ 690:1110-1119. https://doi.org/ 10.1016/j.scitotenv.2019.07.097

Jung EM, An BS, Choi KC, Jeung EB (2012) Potential estrogenic activity of triclosan in the uterus of immature rats and rat pituitary GH3 cells. Toxicol Lett 208(2):142-148. https://doi.org/10. 1016/j.toxlet.2011.10.017

Karnjanapiboonwong A, Suski JG, Shah AA, Cai Q, Morse AN, Anderson TA (2011) Occurrence of PPCPs at a wastewater treatment plant and in soil and groundwater at a land application site. Water Air Soil Pollut 216:257-273. https://doi.org/10.1007/ s11270-010-0532-8

Kaur H, Bansiwal A, Hippargi G, Pophali GR (2018) Effect of hydrophobicity of pharmaceuticals and personal care products for adsorption on activated carbon: adsorption isotherms, kinetics and mechanism. Environ Sci Pollut Res Int 25(21):20473-20485. https://doi.org/10.1007/s11356-017-0054-7

Kaur H, Dahake R, Maddigapu PR, Hippargi G, Pophali GR, Bansiwal A (2020) Enhanced photocatalytic degradation of antimicrobial triclosan using rGO-TiO2 composite under natural solar illumination. J Mater Sci: Mater Electron 31:6045-6058. https://doi. org/10.1007/s10854-020-03156-6

Kenda M, Karas Kuželički N, Iida M, Kojima H, Sollner Dolenc M (2020) Triclocarban, triclosan, bromochlorophene, chlorophene, and climbazole effects on nuclear receptors: an in silico and in vitro study. Environ Health Perspect 128(10):107005. https:// doi.org/10.1289/EHP6596

Khatikarn J, Satapornvanit K, Price OR, Van den Brink PJ (2018) Effects of triclosan on aquatic invertebrates in tropics and the influence of $\mathrm{pH}$ on its toxicity on microalgae. Environ Sci Pollut Res Int 25(14):13244-13253. https://doi.org/10.1007/s11356-016-7302-0
Kim MJ, Park HJ, Lee S, Kang HG, Jeong PS, Park SH, Park YH, Lee JH, Lim KS, Lee SH, Sim BW, Kim SU, Cho SK, Koo DB, Song BS (2020) Effect of triclosan exposure on developmental competence in parthenogenetic porcine embryo during preimplantation. Int J Mol Sci 21(16):5790. https://doi.org/10.3390/ijms21165790

Kim SH, Hwang KA, Shim SM, Choi K (2015) Growth and migration of LNCaP prostate cancer cells are promoted by triclosan and benzophenone-1 via an androgen receptor signaling pathway. Environ Toxicol Pharmacol 39(2):568-576. https://doi.org/10. 1016/j.etap.2015.01.003

Kinney CA, Furlong ET, Kolpin DW, Burkhardt MR, Zaugg SD, Werner SL, Bossio JP, Benotti MJ (2008) Bioaccumulation of pharmaceuticals and other anthropogenic waste indicators in earthworms from agricultural soil amended with biosolid or swine manure. Environ Sci Technol 42(6):1863-1870. https:// doi.org/10.1021/es702304c

Kumar KS, Priya SM, Peck AM, Sajwan KS (2010) Mass loadings of triclosan and triclocarbon from four wastewater treatment plants to three rivers and landfill in Savannah, Georgia, USA. Arch Environ Contam Toxicol 58(2):275-285. https://doi.org/ 10.1007/s00244-009-9383-y

Kwon JT, Yang YS, Kang MS, Seo GB, Lee DH, Yang MJ, Shim I, Kim HM, Kim P, Choi K, Lee K (2013) Pulmonary toxicity screening of triclosan in rats after intratracheal instillation. $\mathbf{J}$ Toxicol Sci 38(3):471-475. https://doi.org/10.2131/jts.38.471

La Merrill MA, Vandenberg LN, Smith MT, Goodson W, Browne P, Patisaul HB, Guyton KZ, Kortenkamp A, Cogliano VJ, Woodruff TJ, Rieswijk L, Sone H, Korach KS, Gore AC, Zeise L, Zoeller RT (2020) Consensus on the key characteristics of endocrine-disrupting chemicals as a basis for hazard identification. Nat Rev Endocrinol 16(1):45-57. https://doi.org/10. 1038/s41574-019-0273-8

Laborie S, Moreau-Guigon E, Alliot F, Desportes A, Oziol L, Chevreuil M (2016) A new analytical protocol for the determination of 62 endocrine-disrupting compounds in indoor air. Talanta 147:132-141. https://doi.org/10.1016/j.talanta.2015. 09.028

Lalonde B, Garron C, Dove A, Struger J, Farmer K, Sekela M, Gledhill M, Backus S (2019) Investigation of spatial distributions and temporal trends of triclosan in Canadian surface waters. Arch Environ Contam Toxicol 76:231-245. https://doi.org/10.1007/ s00244-018-0576-0

Lassen TH, Frederiksen H, Kyhl HB, Swan SH, Main KM, Andersson AM, Lind DV, Husby S, Wohlfahrt-Veje C, Skakkebæk NE, Jensen TK (2016) Prenatal triclosan exposure and anthropometric measures including anogenital distance in Danish infants. Environ Health Perspect 124(8):1261-1268. https://doi.org/10. 1289/ehp. 1409637

Lee HR, Hwang KA, Nam KH, Kim HC, Choi KC (2014) Progression of breast cancer cells was enhanced by endocrine-disrupting chemicals, triclosan and octylphenol, via an estrogen receptordependent signaling pathway in cellular and mouse xenograft models. Chem Res Toxicol 27(5):834-842. https://doi.org/10. $1021 /$ tx 5000156

Lee DG (2015) Removal of a synthetic broad-spectrum antimicrobial agent, triclosan, in wastewater treatment systems: a short review. Environ Eng Res 20:111-120. https://doi.org/10.4491/eer.2014. 081

Lee JD, Lee JY, Kwack SJ, Shin CY, Jang HJ, Kim HY, Kim MK, Seo DW, Lee BM, Kim KB (2019) Risk assessment of triclosan, a cosmetic preservative. Toxicol Res 35(2):137-154. https://doi. org/10.5487/TR.2019.35.2.137

Lehutso RF, Daso AP, Okonkwo JO (2017) Occurrence and environmental levels of triclosan and triclocarban in selected wastewater treatment plants in Gauteng Province, South Africa. Emerg Contam 3:107-114. https://doi.org/10.1016/j.emcon.2017.07.001 
Li L (2021) Toxicity evaluation and by-products identification of triclosan ozonation and chlorination. Chemosphere 263:128223. https://doi.org/10.1016/j.chemosphere.2020.128223

Li X, Ying GG, Su HC, Yang XB, Wang L (2010) Simultaneous determination and assessment of 4-nonylphenol, bisphenol A and triclosan in tap water, bottled water and baby bottles. Environ Int 36(6):557-562. https://doi.org/10.1016/j.envint.2010.04.009

Li X, Ying GG, Zhao JL, Chen ZF, Lai HJ, Su HC (2013) 4-Nonylphenol, bisphenol-A and triclosan levels in human urine of children and students in China, and the effects of drinking these bottled materials on the levels. Environ Int 52:81-86. https://doi.org/10. 1016/j.envint.2011.03.026

Loraine GA, Pettigrove ME (2006) Seasonal variations in concentrations of pharmaceuticals and personal care products in drinking water and reclaimed wastewater in southern California. Environ Sci Technol 40(3):687-695. https://doi.org/10.1021/es051380x

Lu S, Yu Y, Ren L, Zhang X, Liu G, Yu Y (2018) Estimation of intake and uptake of bisphenols and triclosan from personal care products by dermal contact. Sci Total Environ 621:1389-1396. https://doi.org/10.1016/j.scitotenv.2017.10.088

Luo Z, He Y, Zhi D, Luo L, Sun Y, Khan E, Wang L, Peng Y, Zhou Y, Tsang DC (2019) Current progress in treatment techniques of triclosan from wastewater: a review. Sci Total Environ 696:1-10. https://doi.org/10.1016/j.scitotenv.2019.133990

Lydon KA, Robertson MJ, Lipp EK (2018) Patterns of triclosan resistance in Vibrionaceae. PeerJ 6:e5170. https://doi.org/10.7717/ peerj. 5170

Lyndall J, Barber T, Mahaney W, Bock M, Capdevielle M (2017) Evaluation of triclosan in Minnesota lakes and rivers: Part Iecological risk assessment. Ecotoxicol Environ Saf 142:578-587. https://doi.org/10.1016/j.ecoenv.2017.04.049

Ma X, Wan Y, Wu M, Xu Y, Xu Q, He Z, Xia W (2018) Occurrence of benzophenones, parabens and triclosan in the Yangtze River of China, and the implications for human exposure. Chemosphere 213:517-525. https://doi.org/10.1016/j.chemosphere.2018.09. 084

Ma Y, Guo Y, Ye H, Zhang J, Ke Y (2020) Perinatal Triclosan exposure in the rat induces long-term disturbances in metabolism and gut microbiota in adulthood and old age. Environ Res 182:109004. https://doi.org/10.1016/j.envres.2019.109004

Madikizela LM, Muthwa SF, Chimuka L (2014) Determination of triclosan and ketoprofen in river water and wastewater by solid phase extraction and high performance liquid chromatography. S Afr J Chem 67(1):143-150. https://hdl.handle.net/10520/EJC15 9632

Matamoros V, Arias CA, Nguyen LX, Salvadó V, Brix H (2012) Occurrence and behavior of emerging contaminants in surface water and a restored wetland. Chemosphere 88(9):1083-1089. https:// doi.org/10.1016/j.chemosphere.2012.04.048

Mendez MO, Valdez EM, Martinez EM, Saucedo M, Wilson BA (2016) Fate of triclosan in irrigated soil: degradation in soil and translocation into onion and tomato. J Environ Qual 45(3):10291035. https://doi.org/10.2134/jeq2015.07.0386

Milanović M, Milošević N, Sudji J, Stojanoski S, Atanacković Krstonošić M, Bjelica A, Milić N, Medić Stojanoska M (2020) Can environmental pollutant bisphenol A increase metabolic risk in polycystic ovary syndrome? Clin Chim Acta 507:257-263. https://doi.org/10.1016/j.cca.2020.05.009

Milanović M, Sudji J, Grujić Letić N, Radonić J, Turk Sekulić M, Vojinović Miloradov M, Milić N (2016) Seasonal variations of bisphenol A in the Danube by the Novi Sad municipality. Serbia J Serb Chem Soc 80(3):333-345. https://doi.org/10.2298/JSC15 0721095M

Milić N, Četojević-Simin D, Milanović M, Sudji J, Milošević N, Curić N, Abenavoli L, Medić-Stojanoska M (2015) Estimation of in vivo and in vitro exposure to bisphenol $\mathrm{A}$ as food contaminant.
Food Chem Toxicol 83:268-274. https://doi.org/10.1016/j.fct. 2015.07.003

Milošević N, Jakšić V, Suđi J, Vuković B, Ičin T, Milić N, Medić Stojanoska M (2017) Possible influence of the environmental pollutant bisphenol A on the cardiometabolic risk factors. Int J Environ Health Res 27(1):11-26. https://doi.org/10.1080/09603 123.2016.1246654

Milošević N, Milanović M, Sudji J, Bosić Živanović D, Stojanoski S, Vuković B, Milić N, Medić Stojanoska M (2020) Could phthalates exposure contribute to the development of metabolic syndrome and liver disease in humans? Environ Sci Pollut Res Int 27(1):772-784. https://doi.org/10.1007/s11356-019-06831-2

Milošević N, Milić N, Živanović Bosić D, Bajkin I, Perčić I, Abenavoli L, Medić Stojanoska M (2018) Potential influence of the phthalates on normal liver function and cardiometabolic risk in males. Environ Monit Assess 190:17. https://doi.org/10.1007/ s10661-017-6398-0

Mohammed AT, Mohamed AA, Ali H (2017) Pulmonary apoptotic and oxidative damaging effects of Triclosan alone or in combination with Fluoride in Sprague Dawley rats. Acta Histochem 119(4):357-363. https://doi.org/10.1016/j.acthis.2017.03.004

Montaseri H, Forbes PBC (2016) A review of monitoring methods for triclosan and its occurrence in aquatic environments. TracTrend Anal Chem 85:221-231. https://doi.org/10.1016/j.trac. 2016.09.010

Moos RK, Angerer J, Wittsiepe J, Wilhelm M, Brüning T, Koch HM (2014) Rapid determination of nine parabens and seven other environmental phenols in urine samples of German children and adults. Int J Hyg Environ Health 217(8):845-853. https:// doi.org/10.1016/j.ijheh.2014.06.003

Moss T, Howes D, Williams FM (2000) Percutaneous penetration and dermal metabolism of triclosan $(2,4,4$ '-trichloro-2'hydroxydiphenyl ether). Food Chem Toxicol 38(4):361-370. https://doi.org/10.1016/S0278-6915(99)00164-7

Mpupa A, Mashile G, Nomngongo P (2017) Vortex assisted-supramolecular solvent based microextraction coupled with spectrophotometric determination of triclosan in environmental water samples. Open Chem 15(1):255-262. https://doi.org/10.1515/ chem-2017-0032

Mukherjee S, Boral S, Siddiqi H, Mishra A, Meikap BC (2021) Present cum future of SARS-CoV-2 virus and its associated control of virus-laden air pollutants leading to potential environmental threat-a global review. J Environ Chem Eng 9(2):104973. https://doi.org/10.1016/j.jece.2020.104973

National Institute of Environmental Health Sciences (NIEHS) (2020) Endocrine disruptors. https://www.niehs.nih.gov/health/topics/ agents/endocrine/index.cfm Accessed 5th Jan 2021

Nishi I, Kawakami T, Onodera S (2008) Monitoring of triclosan in the surface water of the Tone Canal, Japan. Bull Environ Contam Toxicol 80:163-166. https://doi.org/10.1007/ s00128-007-9338-9

Olaniyan LW, Mkwetshana N, Okoh AI (2016) Triclosan in water, implications for human and environmental health. Springerplus 5(1):1639. https://doi.org/10.1186/s40064-016-3287-x

Ouyang F, Tang N, Zhang HJ, Wang X, Zhao S, Wang W, Zhang J, Cheng W (2018) Maternal urinary triclosan level, gestational diabetes mellitus and birth weight in Chinese women. Sci Total Environ 626:451-457. https://doi.org/10.1016/j.scitotenv.2018.01.102

Pannu MW, Toor GS, O'Connor GA, Wilson PC (2012) Toxicity and bioaccumulation of biosolids-borne triclosan in food crops. Environ Toxicol Chem 31(9):2130-2137. https://doi.org/10.1002/etc. 1930

Park BK, Gonzales EL, Yang SM, Bang M, Choi CS, Shin CY (2016) Effects of triclosan on neural stem cell viability and survival. Biomol Ther (seoul) 24(1):99-107. https://doi.org/10.4062/ biomolther.2015.164 
Park HJ, Song BS, Kim JW, Yang SG, Kim SU, Koo DB (2020) Exposure of triclosan in porcine oocyte leads to superoxide production and mitochondrial-mediated apoptosis during in vitro maturation. Int J Mol Sci 21(9):3050. https://doi.org/10.3390/ijms21093050

Park M, Kim S, Kim Y, Nam DJ, Ryoo JH, Lim S (2019) Relationship between personal care products usage and triclosan exposure: the second Korean National Environmental Health Survey (KoNEHS 2012-2014). Ann Occup Environ Med 31:2. https://doi.org/10. 1186/s40557-019-0283-y

Perez AL, De Sylor MA, Slocombe AJ, Lew MG, Unice KM, Donovan EP (2013) Triclosan occurrence in freshwater systems in the United States (1999-2012): a meta-analysis. Environ Toxicol Chem 32(7):1479-1487. https://doi.org/10.1002/etc.2217

Petrie B, Youdan J, Barden R, Kasprzyk-Hordern B (2016) Multiresidue analysis of 90 emerging contaminants in liquid and solid environmental matrices by ultra-high-performance liquid chromatography tandem mass spectrometry. J Chromatogr A 1431:64-78. https://doi.org/10.1016/j.chroma.2015.12.036

Pintado-Herrera MG, González-Mazo E, Lara-Martín PA (2014) Atmospheric pressure gas chromatography-time-of-flightmass spectrometry (APGC-ToF-MS) for the determination of regulated and emerging contaminants in aqueous samples after stir bar sorptive extraction (SBSE). Anal Chim Acta 851:1-13. https://doi.org/10.1016/j.aca.2014.05.030

Pirard C, Sagot C, Deville M, Dubois N, Charlier C (2012) Urinary levels of bisphenol A, triclosan and 4-nonylphenol in a general Belgian population. Environ Int 48:78-83. https://doi.org/10. 1016/j.envint.2012.07.003

Pollock T, Greville LJ, Tang B, deCatanzaro D (2016) Triclosan elevates estradiol levels in serum and tissues of cycling and peri-implantation female mice. Reprod Toxicol 65:394-401. https://doi.org/10.1016/j.reprotox.2016.09.004

Provencher G, Bérubé R, Dumas P, Bienvenu JF, Gaudreau E, Bélanger P, Ayotte P (2014) Determination of bisphenol A, triclosan and their metabolites in human urine using isotope-dilution liquid chromatography-tandem mass spectrometry. J Chromatogr A 1348:97-104. https://doi.org/10.1016/j.chroma.2014.04.072

Queckenberg C, Meins J, Wachall B, Doroshyenko O, Tomalik-Scharte D, Bastian B, Abdel-Tawab M, Fuhr U (2010) Absorption, pharmacokinetics, and safety of triclosan after dermal administration. Antimicrob Agents Chemother 54(1):570-572. https://doi.org/ 10.1128/AAC.00615-09

Ramaswamya BR, Shanmugama G, Velua G, Rengarajana B, Joakim Larssonb DG (2011) GC-MS analysis and eco toxicological risk assessment of triclosan, carbamazepine and parabens in Indian rivers. J Hazard Mater 186:1586-1593. https://doi.org/10.1016/j. jhazmat.2010.12.037

Reiss R, Mackay N, Habig C, Griffin J (2002) An ecological risk assessment for triclosan in lotic systems following discharge from wastewater treatment plants in the United States. Environ Toxicol Chem 21(11):2483-2492. https://doi.org/10.1002/etc. 5620211130

Rocha BA, de Oliveira SR, da Silva RM, Barcelos GRM, de Oliveira ARM, Barbosa F (2019) An eco-friendly sample preparation procedure base on low-density solvent-based air-assisted liquidliquid microextraction for the simultaneous determination of 21 potential endocrine disruptors in urine samples by liquid chromatography-tandem mass spectrometry. Microchem J 147:207-214. https://doi.org/10.1016/j.microc.2019.03.019

Rundle CW, Presley CL, Militello M, Barber C, Powell DL, Jacob SE, Atwater AR, Watsky KL, Yu J, Dunnick CA (2020) Hand hygiene during COVID-19: Recommendations from the American Contact Dermatitis Society. J Am Acad Dermatol 83(6):1730-1737. https://doi.org/10.1016/j.jaad.2020.07.057

Sandborgh-Englund G, Adolfsson-Erici M, Odham G, Ekstrand J (2006) Pharmacokinetics of triclosan following oral ingestion in humans. J Toxicol Environ Health A 69(20):1861-1873. https:// doi.org/10.1080/15287390600631706

Schebb NH, Inceoglu B, Ahn KC, Morisseau C, Gee SJ, Hammock BD (2011) Investigation of human exposure to triclocarban after showering and preliminary evaluation of its biological effects. Environ Sci Technol 45(7):3109-3115. https://doi.org/10.1021/ es103650m

Scientific Committee on Consumer Safety (SCCS) (2011) Opinion on Triclosan. https://ec.europa.eu/health/scientific_committees/ consumer_safety/docs/sccs_o_054.pdf Accessed 20th Feb 2021

Shane HL, Othumpangat S, Marshall NB, Blachere F, Lukomska E, Weatherly LM, Baur R, Noti JD, Anderson SE (2020) Topical exposure to triclosan inhibits Th1 immune responses and reduces $\mathrm{T}$ cells responding to influenza infection in mice. PLoS ONE 15(12):e0244436. https://doi.org/10.1371/journal.pone.0244436

Shapiro GD, Arbuckle TE, Ashley-Martin J, Fraser WD, Fisher M, Bouchard MF, Monnier P, Morisset AS, Ettinger AS, Dodds L (2018) Associations between maternal triclosan concentrations in early pregnancy and gestational diabetes mellitus, impaired glucose tolerance, gestational weight gain and fetal markers of metabolic function. Environ Res 161:554-561. https://doi.org/ 10.1016/j.envres.2017.12.001

Shekhar S, Sood S, Showkat S, Lite C, Chandrasekhar A, Vairamani M, Barathi S, Santosh W (2017) Detection of phenolic endocrine disrupting chemicals (EDCs) from maternal blood plasma and amniotic fluid in Indian population. Gen Comp Endocrinol 241:100-107. https://doi.org/10.1016/j.ygcen.2016.05.025

Sheng C, Ahwu Nnanna AG, Liu Y, Vargo JD (2016) Removal of trace pharmaceuticals from water using coagulation and powdered activated carbon as pre-treatment to ultrafiltration membrane system. Sci Tota Environ 550:1075-1083. https://doi.org/ 10.1016/j.scitotenv.2016.01.179

Shi Y, Liu X, Zhang J, Shao B (2013) Analysis of triclosan and triclocarban in human nails using isotopic dilution liquid chromatography-tandem mass spectrometry. J Chromatogr B Analyt Technol Biomed Life Sci 934:97-101. https://doi.org/10.1016/j.jchromb. 2013.07.003

Singer H, Muller S, Tixier C, Pillonel L (2002) Triclosan: occurrence and fate of a widely used biocide in the aquatic environment: field measurements in wastewater treatment plants, surface waters, and lake sediments. Environ Sci Technol 36:4998-5004. https://doi.org/10.1021/es025750i

Solak S, Vakondios N, Tzatzimaki I, Diamadopoulos E, Arda M, Kabay N, Yüksel M (2014) A comparative study of removal of endocrine disrupting compounds (EDCs) from treated wastewater using highly cross linked polymeric adsorbents and activated carbon. J Chem Technol Biotechnol 89:819-824. https://doi.org/ $10.1002 /$ jctb. 4315

Sorensen JP, Lapworth DJ, Nkhuwa DC, Stuart ME, Gooddy DC, Bell RA, Chirwa M, Kabika J, Liemisa M, Chibesa M, Pedley S (2015) Emerging contaminants in urban groundwater sources in Africa. Water Res 72:51-63. https://doi.org/10.1016/j.watres. 2014.08.002

Subramanya SH, Czyż DM, Acharya KP, Humphreys H (2021) The potential impact of the COVID-19 pandemic on antimicrobial resistance and antibiotic stewardship. Virus Dis 32(2):330-337. https://doi.org/10.1007/s13337-021-00695-2

Szychowski KA, Sitarz AM, Wojtowicz AK (2015) Triclosan induces Fas receptor-dependent apoptosis in mouse neocortical neurons in vitro. Neuroscience 284:192-201. https://doi.org/10.1016/j. neuroscience.2014.10.001

Szychowski KA, Wnuk A, Rzemieniec J, Kajta M, Leszczyńska T, Wójtowicz AK (2019) Triclosan-evoked neurotoxicity involves NMDAR subunits with the specific role of GluN2A in caspase3-dependent apoptosis. Mol Neurobiol 56(1):1-12. https://doi. org/10.1007/s12035-018-1083-z 
Tabari SA, Esfahani ML, Hosseini SM, Rahimi A (2019) Neurobehavioral toxicity of triclosan in mice. Food Chem Toxicol 130:154 160. https://doi.org/10.1016/j.fct.2019.05.025

Taha M, Marie AM, Ahmed-Farid OA (2020) Combined approaches for evaluation of xenoestrogen neural toxicity and thyroid dysfunction: screening of oxido-nitrosative markers, DNA fragmentation, and biogenic amine degradation. J Biochem Mol Toxicol e22521. https://doi.org/10.1002/jbt.22521

Tang Y, Vanlandingham M, M, Wu Y, Beland FA, Olson GR, Fang JL, (2018) Role of peroxisome proliferator-activated receptor alpha (PPAR $\alpha)$ and PPAR $\alpha$-mediated species differences in triclosan-induced liver toxicity. Arch Toxicol 92(11):3391-3402. https://doi.org/10.1007/s00204-018-2308-7

Tanner EM, Hallerbäck MU, Wikström S, Lindh C, Kiviranta H, Gennings C, Bornehag CG (2020) Early prenatal exposure to suspected endocrine disruptor mixtures is associated with lower IQ at age seven. Environ Int 134:105185. https://doi.org/ 10.1016/j.envint.2019.105185

Tohidi F, Cai Z (2015) GC/MS analysis of triclosan and its degradation by-products in wastewater and sludge samples from different treatments. Environ Sci Pollut Res Int 22(15):1138711400. https://doi.org/10.1007/s11356-015-4289-x

Tran DN, Jung EM, Yoo YM, Lee JH, Jeung EB (2020) Perinatal exposure to triclosan results in abnormal brain development and behavior in mice. Int J Mol Sci 21(11):4009. https://doi. org/10.3390/ijms21114009

Usman M, Farooq M, Hanna K (2020) Environmental side effects of the injudicious use of antimicrobials in the era of COVID-19. Sci Total Environ 745:141053. https://doi.org/10.1016/j.scito tenv.2020.141053

von der Ohe PC, Dulio V, Slobodnik J, De Deckere E, Kühne R, Ebert R-U, Ginebreda A, De Cooman W, Schüürmann G, Brack W (2011) A new risk assessment approach for the prioritization of 500 classical and emerging organic microcontaminants as potential river basin specific pollutants under the European Water Framework Directive. Sci Total Environ 409:20642077. https://doi.org/10.1016/j.scitotenv.2011.01.054

von der Ohe PC, Schmitt-Jansen M, Slobodnik J, Brack W (2012) Triclosan-the forgotten priority substance? Environ Sci Pollut Res Int 19(2):585-591. https://doi.org/10.1007/ s11356-011-0580-7

Wang Q, Kelly BC (2017) Occurrence and distribution of synthetic musks, triclosan and methyl triclosan in a tropical urban catchment: influence of land-use proximity, rainfall and physicochemical properties. Sci Total Environ 574:1439-1447. https://doi.org/ 10.1016/j.scitotenv.2016.08.091

Wang X, Ouyang F, Feng L, Wang X, Liu Z, Zhang J (2017) Maternal urinary triclosan concentration in relation to maternal and neonatal thyroid hormone levels: a prospective study. Environ Health Perspect 125(6):067017. https://doi.org/10.1289/EHP500

Wang Y, Liang W (2021) Occurrence, toxicity, and removal methods of triclosan: a timely review. Curr Pollution Rep 7:31-39. https:// doi.org/10.1007/s40726-021-00173-9

Wang Y, Li G, Zhu Q, Liao C (2021) Occurrence of parabens, triclosan and triclocarban in paired human urine and indoor dust from two typical cities in China and its implications for human exposure. Sci Total Environ 786:147485. https://doi.org/10.1016/j.scito tenv.2021.147485

Ward JB, Casagrande SS, Cowie CC (2020) Urinary phenols and parabens and diabetes among US adults, NHANES 2005-2014. Nutr Metab Cardiovasc Dis 30(5):768-776. https://doi.org/10.1016/j. numecd.2020.01.005

Weatherly LM, Nelson AJ, Shim J, Riitano AM, Gerson ED, Hart AJ, de Juan-Sanz J, Ryan TA, Sher R, Hess ST, Gosse JA (2018) Antimicrobial agent triclosan disrupts mitochondrial structure, revealed by super-resolution microscopy, and inhibits mast cell signaling via calcium modulation. Toxicol Appl Pharmacol 349:39-54. https://doi.org/10.1016/j.taap.2018.04.005

Weatherly LM, Gosse JA (2017) Triclosan exposure, transformation, and human health effects. J Toxicol Environ Health B Crit Rev 20(8):447-469. https://doi.org/10.1080/10937404.2017.1399306

Wee SY, Haron D, Aris AZ, Yusoff FM, Praveena SM (2020) Active pharmaceutical ingredients in Malaysian drinking water: consumption, exposure, and human health risk. Environ Geochem Health 42(10):3247-3261. https://doi.org/10.1007/ s10653-020-00565-8

Westfall C, Flores-Mireles AL, Robinson JI, Lynch AJL, Hultgren S, Henderson JP, Levin PA (2019) The widely used antimicrobial triclosan induces high levels of antibiotic tolerance in vitro and reduces antibiotic efficacy up to 100 -fold in vivo. Antimicrob Agents Chemother 63(5):e02312-e02318. https://doi.org/10. 1128/AAC.02312-18

Winitthana T, Lawanprasert S, Chanvorachote P (2014) Triclosan potentiates epithelial-to-mesenchymal transition in anoikisresistant human lung cancer cells. PLoS ONE 9(10):e110851. https://doi.org/10.1371/journal.pone.0110851

Winkler G, Thompson A, Fischer R, Krebs P, Grifn P, Cartmell E (2007) Mass flow balances of triclosan in small rural wastewater treatment plants and the impact of biomass parameters on the removal. Eng Life Sci 7:42-51. https://doi.org/10.1002/elsc. 200620158

Wise SA, Barceló D, Garrigues P, Turle R (2006) Advances in analytical techniques for environmental analysis. Anal Bioanal Chem 386(4):765-767. https://doi.org/10.1007/s00216-006-0768-8

Wu Y, Beland FA, Chen S, Fang JL (2015) Extracellular signal-regulated kinases $1 / 2$ and Akt contribute to triclosan-stimulated proliferation of JB6 Cl 41-5a cells. Arch Toxicol 89(8):1297-1311. https://doi.org/10.1007/s00204-014-1308-5

Wu Y, Beland FA, Fang JL (2016) Effect of triclosan, triclocarban, $2,2^{\prime}, 4,4^{\prime}$-tetrabromodiphenyl ether, and bisphenol $\mathrm{A}$ on the iodide uptake, thyroid peroxidase activity, and expression of genes involved in thyroid hormone synthesis. Toxicol in Vitro 32:310-319. https://doi.org/10.1016/j.tiv.2016.01.014

Yang H, Wang W, Romano KA, Gu M, Sanidad KZ, Kim D, Yang J, Schmidt B, Panigrahy D, Pei R, Martin DA, Ozay EI, Wang Y, Song M, Bolling BW, Xiao H, Minter LM, Yang G-Y, Liu Z, Rey FE, Yhang G (2018) A common antimicrobial additive increases colonic inflammation and colitis-associated colon tumorigenesis in mice. Sci Transl Med 10(443):eaan4116. https://doi.org/10. 1126/scitranslmed.aan4116

Yang YS, Kwon JT, Shim I, Kim HM, Kim P, Kim JC, Lee K (2015) Evaluation of toxicity to triclosan in rats following 28 days of exposure to aerosol inhalation. Regul Toxicol Pharmacol 71(2):259-268. https://doi.org/10.1016/j.yrtph.2015.01.004

Yang GC, Yen CH, Wang CL (2014) Monitoring and removal of residual phthalate esters and pharmaceuticals in the drinking water of Kaohsiung City. Taiwan J Hazard Mater 277:53-61. https://doi. org/10.1016/j.jhazmat.2014.03.005

Yao L, Lv YZ, Zhang LJ, Liu WR, Zhao JL, Yang YY, Jia YW, Liu YS, He LY, Ying GG (2019) Bioaccumulation and risks of 24 personal care products in plasma of wild fish from the Yangtze River, China. Sci Total Environ 665:810-819. https://doi.org/10. 1016/j.scitotenv.2019.02.176

Ye J, Zhu W, Liu H, Mao Y, Jin F, Zhang J (2018) Environmental exposure to triclosan and polycystic ovary syndrome: a crosssectional study in China. BMJ Open 8(10):e019707. https://doi. org/10.1136/bmjopen-2017-019707

Ying GG, Kookana RS (2007) Triclosan in wastewaters and biosolids from Australian wastewater treatment plants. Environ Int 33(2):199-205. https://doi.org/10.1016/j.envint.2006.09.008

Yueh MF, He F, Chen C, Vu C, Tripathi A, Knight R, Karin M, Chen S, Tukey RH (2020) Triclosan leads to dysregulation of the 
metabolic regulator FGF21 exacerbating high fat diet-induced nonalcoholic fatty liver disease. Proc Natl Acad Sci USA 117(49):31259-31266. https://doi.org/10.1073/pnas.2017129117

Zhang P, Yang M, Zeng L, Liu C (2018) P38/TRHr-dependent regulation of TPO in thyroid cells contributes to the hypothyroidism of triclosan-treated rats. Cell Physiol Biochem 45(4):1303-1315. https://doi.org/10.1159/000487558

Zhang H, Li J, Chen Y, Wang D, Xu W, Gao Y (2021) Profiles of parabens, benzophenone-type ultraviolet filters, triclosan, and triclocarban in paired urine and indoor dust samples from Chinese university students: implications for human exposure. Sci
Total Environ 798:149275. https://doi.org/10.1016/j.scitotenv. 2021.149275

Zhu Q, Wang M, Jia J, Hu Y, Wang X, Liao C, Jiang G (2020) Occurrence, distribution, and human exposure of several endocrinedisrupting chemicals in indoor dust: a nationwide study. Environ Sci Technol 54(18):11333-11343. https://doi.org/10.1021/acs. est.0c04299

Publisher's note Springer Nature remains neutral with regard to jurisdictional claims in published maps and institutional affiliations. 